\title{
El Chichon Volcanic Aerosols: Impact of Radiative, Thermal, and Chemical Perturbations
}

\author{
Diane V. Michelangeli, Mark Allen, ${ }^{1}$ ANd YuK L. Yung \\ Division of Geological and Planetary Sciences, California Institute of Technology, Pasadena
}

\begin{abstract}
We examine the consequences of the eruption of the El Chichon volcano on the Earth's stratospheric chemistry. Formed after the eruption, the volcanic aerosol cloud, with a peak particle density at $27 \mathrm{~km}$, was very efficient at altering the radiation field. The results of a one-dimensional radiative transfer model show that the total radiation increased by $8 \%$ within the aerosol layer longward of $3000 \AA$. At certain altitudes and wavelengths below $3000 \AA$, the total radiation decreased by $15 \%$. Consequently, there are changes in the photolysis rates obtained with a onedimensional photochemical model: for example, $\mathrm{O}_{2}$ photodissociation rate constants decrease by $10 \%$, while $\mathrm{O}_{3}$ photodissociation rate constants increase by a comparable amount. A combination of this radiation change and the effect of a temperature variation of a few degrees causes the abundance of $\mathrm{O}_{3}$ to decrease by $7 \%$ at $24 \mathrm{~km}$, in good agreement with the Solar Backscattered Ultraviolet experiment (SBUV) measurements of a 5-10\% decrease. The combined radiative and thermal perturbations on the concentrations of $\mathrm{O}, \mathrm{O}\left({ }^{1} D\right), \mathrm{OH}, \mathrm{HO}_{2}, \mathrm{H}_{2} \mathrm{O}_{2}, \mathrm{NO}, \mathrm{NO}_{2}, \mathrm{NO}_{3}$, $\mathrm{N}_{2} \mathrm{O}_{5}, \mathrm{HNO}_{3}, \mathrm{HO}_{2} \mathrm{NO}_{2}, \mathrm{Cl}, \mathrm{ClO}, \mathrm{ClO}_{2}, \mathrm{HOCl}, \mathrm{ClNO}_{3}$, and $\mathrm{HCl}$ are computed and presented in detail. However, these changes as calculated are insufficient to explain the observations of significant decreases in $\mathrm{NO}$ and $\mathrm{NO}_{2}$ and increases in $\mathrm{HCl}$. A heterogeneous reaction catalyzed by aerosol surfaces which transforms $\mathrm{ClNO}_{3}$ into $\mathrm{HCl}$ provides a pathway for sequestering $\mathrm{NO}_{x}$, and at the same time reduces $\mathrm{ClNO}_{3}$ in favor of $\mathrm{HCl}$. The inclusion of this reaction in the model leads to a satisfactory single-step explanation of the otherwise puzzling observations of $\mathrm{NO}_{1} \mathrm{NO}_{2}$, and $\mathrm{HCl}$. The observed lack of change in $\mathrm{HNO}_{3}$ cannot be explained by this hypothesis. The effects of a number of heterogenous reactions, some believed to be important for the Antarctic stratosphere, have been assessed with our model. We also examine the hypothesis of direct injection of gases from the volcano into the stratosphere. Only an unrealistically large injection (60\% column increase above $12 \mathrm{~km}$ ) results in an $\mathrm{HCl}$ increase in agreement with observations. An equally large water injection decreases $\mathrm{HCl}$, and decreases the $\mathrm{NO}$ and $\mathrm{NO}_{2}$ by as much as $20 \%$, but still does not simulate the observed $\mathrm{NO}_{x}$ decrease.
\end{abstract}

\section{INTRODUCTION}

Interest in developing comprehensive stratospheric photochemical models emerged when it was realized that anthropogenically produced halocarbons had an adverse impact on the ozone layer [Molina and Rowland, 1974; Rowland and Molina, 1975; Cicerone et al., 1983; Prather et al., 1984]. The long-term effects of man-made pollutants can only be predicted accurately with models that are a complete description of important atmospheric processes. Stratospheric photochemical modeling has undergone many stages of refinement; a critical evaluation of remaining problems was made by Watson et al. [1985]. Nevertheless, the models still do not adequately reproduce the ensemble of ozone concentration measurements above $35 \mathrm{~km}$ (see, for example, Watson et al. [1985] and, most recently, McElroy and Salawitch [1989]). Finding the explanation of the newly discovered "ozone hole" over Antarctica, appearing each spring [Farman et al., 1985], is a new challenge for stratospheric modeling.

One of the best ways of testing the completeness of our photochemical model in representing the atmosphere is by studying its response to a known change. The time scale for the response has to be short enough that we may observe the changes in the atmosphere. For example, it is difficult to

\footnotetext{
${ }^{1}$ Also at Jet Propulsion Laboratory, California Institute of Technology, Pasadena, California.
}

Copyright 1989 by the American Geophysical Union.

Paper number 89JD01149. 0148-0227/89/89JD-01149\$05.00 evaluate whether or not our models respond well to halocarbon, $\mathrm{CO}_{2}$ or $\mathrm{CH}_{4}$ injections, because the atmosphere takes many years to show a measurable effect. Some examples of useful changes that can be studied are the diurnal and seasonal variations seen in concentration profiles, and the consequences of solar eclipses, and volcanic eruptions.

When the stratospheric aerosol concentration increases suddenly, because of an explosive volcanic eruption, we expect the atmosphere to respond. There are measured variations in temperature, radiation field, general weather patterns, planetary albedo, and chemical species concentrations. Based on the current understanding of the scattering and chemical properties of volcanic aerosols, we can use models to investigate the impact of the presence of the aerosols, and calculate, for example, changes in the radiation field and species concentrations. If the predictions of the model are in good agreement with the observations of changes after the eruption, we can conclude that the theoretical model is a complete description of stratospheric processes.

In this work, we investigate the impact on the stratosphere of the March-April 1982 eruptions of the El Chichon volcano $\left(17.33^{\circ} \mathrm{N}, 9^{3.2}{ }^{\circ} \mathrm{W}\right)$ [e.g., Pollack et al., 1983]. There was an injection of more than $10^{12} \mathrm{~g}$ of $\mathrm{SO}_{2}$ into the stratosphere at $30 \mathrm{~km}$ [Krueger, 1983]. The $\mathrm{SO}_{2}$ was oxidized to $\mathrm{SO}_{3}$, which subsequently reacted with water to form $\mathrm{H}_{2} \mathrm{SO}_{4}$. After condensation, sulfuric acid aerosols (composed of $75 \%$ $\mathrm{H}_{2} \mathrm{SO}_{4}$, and $25 \% \mathrm{H}_{2} \mathrm{O}$ ) were formed [Hofmann and Rosen, 1984]. After 3 weeks, the volcanic cloud had circled the globe between 0 and $30^{\circ} \mathrm{N}$. The altitude of the peak aerosol concentration had dropped to $27 \mathrm{~km}$ after 8 weeks [Barth et al., 1983]. 
These first stages of the impact of the eruption on the stratosphere were investigated by McKeen et al. [1984]. They modeled the chemical effects of the formation of $\mathrm{H}_{2} \mathrm{SO}_{4}$, and compared their calculated $\mathrm{SO}_{2}$ chemical lifetimes with observations. In this way, they were able to put constraints on the formation of sulfate. Their calculations showed that the formation of sulfate from $\mathrm{HSO}_{3}$ had to regenerate $\mathrm{HO}_{x}$ in order to be consistent with the $\mathrm{SO}_{2}$ chemical lifetime observed (30-40 days). This resulted in no net change in $\mathrm{HO}_{x}$; therefore, once the aerosols were formed, the atmosphere had returned to its original chemical state.

The photochemical calculations of McKeen et al. [1984] simulated the chemical response of the atmosphere to the formation of $\mathrm{H}_{2} \mathrm{SO}_{4}$ from the $\mathrm{SO}_{2}$ injected during the volcanic eruption. Thomas et al. [1983] found that the peak in the optical depth of the aerosol cloud was reached 15 weeks after the eruption. After that date, the decline was consistent with the gravitational settling time. Therefore all important chemical effects that were due to the process of formation of the sulfate particles, as modeled by McKeen et al. [1984], were complete by July. McKeen et al. [1984] did not consider any radiative effect resulting from the increased scattering caused by the aerosol cloud. The optical depth of the stratospheric aerosols was near 0.25 at 6000-7000 § [DeLuisi et al., 1983] in June-July 1982. This is a substantial increase in the aerosol content of the stratosphere, because the background level of the aerosol optical depth is only about $10^{-3}$ [e.g., Wang and McCormick, 1985]. This aerosol-cloud layer, spread out between 16 and $30 \mathrm{~km}$ [DeLuisi et al., 1983], was still observable a year after the eruption [Hofmann and Rosen, 1983; Thomas et al., 1983; Adriani et al., 1983; Spinhirne and King, 1985]. Jäger and Carnuth [1987] tracked the aerosol layer until the end of 1985. Therefore the impact of this cloud on the stratosphere could be significant. Pollack and Ackerman [1983] showed theoretically that the volcanic cloud increased the planetary albedo, decreased the temperature and solar radiation below the cloud, and increased the temperature within the cloud. This last prediction matched the observations of Labitzke et al. [1983] and Quiroz [1983].

The aerosols change the radiation field in the stratosphere and therefore have a direct effect on photolysis rates, and on concentrations of species. One purpose of this study is first to investigate and quantify the effect of the El Chichon volcanic aerosols on the chemistry of the stratosphere through the radiation changes. To study the radiation field, we first use a one-dimensional radiative-transfer model (D. V. Michelangeli et al., manuscript in preparation, 1989) to calculate the total actinic flux (attenuated solar beam and scattered flux) within the stratosphere. This is done for a standard "clear" model atmosphere, and for an "aerosolcontaining" one based on the observational data of the El Chichon stratospheric aerosols. With a one-dimensional chemical kinetics model [Froidevaux et al., 1985] that uses the diffuse actinic flux values from the radiative transfer model, the changes in photochemical rates and concentrations resulting from the inclusion of aerosols are studied. A temperature perturbation based on calculated changes is also added to the aerosol-containing case.

We focus our discussion on observed changes in the concentrations of $\mathrm{O}_{3}, \mathrm{HCl}, \mathrm{NO}, \mathrm{NO}_{2}, \mathrm{HNO}_{3}$, and $\mathrm{OH}$ after the eruption of the volcano. Only for these species are measurements available from the same instrument near $20^{\circ} \mathrm{N}$ lati- tude before, and 3-6 months after, the eruption of El Chichon. Therefore, even though there were many observations after April 1982, we focus on data summarized in Table 1 for the purpose of understanding what changes occurred in the atmosphere as a result of the eruption. Radiative and thermal perturbations introduced into our model calculations can explain the observed $\mathrm{O}_{3}$ changes but fail to account for the changes in the other species listed above. Other processes, necessarily more speculative, must be invoked to explain almost all the observations simultaneously.

Many new ideas have blossomed in the face of the challenge to explain the Antarctic ozone hole. Perhaps the most fruitful of these ideas is that the polar stratospheric clouds, present during the polar winter, act as catalytic surfaces for reactions involving $\mathrm{N}_{2} \mathrm{O}_{5}, \mathrm{ClNO}_{3}, \mathrm{HCl}$, and $\mathrm{H}_{2} \mathrm{O}$ [Solomon et al., 1986; McElroy et al., 1986; Molina et al., 1987; Tolbert et al., 1987]. There is now evidence that such heterogeneous reactions may have a universal character. For instance, they are believed to be responsible for the "unusual" springtime photochemistry recently observed in the Arctic stratosphere campaign (C. B. Farmer, private communication, 1989). In this work we find that invoking a heterogeneous reaction of the form,

$$
\mathrm{ClNO}_{3} \rightarrow \mathrm{HCl}
$$

on the surface of volcanic aerosols (the $\mathrm{NO}_{3}$ is sequestered in the aerosol) provides a satisfactory explanation of the observed changes in $\mathrm{HCl}, \mathrm{NO}$, and $\mathrm{NO}_{2}$. Thus combining the results due to radiative and thermal perturbations and a heterogeneous reaction, we can explain all the observations summarized in Table 1 except for $\mathrm{HNO}_{3}$ and $\mathrm{OH}$. As discussed later, we believe that the $\mathrm{OH}$ observations are in error. The $\mathrm{HNO}_{3}$ observation requires an alternative explanation.

Two types of results, of very different nature, are reported here. The first part is the rigorous and compelling consequences of the impact of well-established radiative and thermal perturbations on stratospheric species. The results are important for explaining the observed $\mathrm{O}_{3}$ changes and seem to agree qualitatively with the observation of other species, but these results fail to quantitatively account for all the observed changes in species abundances. Nevertheless, we believe that a complete discussion of these results is important for their own sake, for the insights they provide to current models of stratospheric chemistry, and for planning future stratospheric observations after a volcanic eruption. The second part of the paper concerns heterogeneous reactions. Here, we face a problem which is opposite that of the first part of the paper, in that we are trying to constrain the nature of the mechanism of the perturbation by fitting the observations. We find a heterogeneous reaction that can reasonably simulate the observations, but we cannot rigorously prove that it is unique. To demonstrate that this solution is more plausible than the other solutions, we explore a number of other heterogeneous reactions which have been postulated to be important in the Antarctic stratosphere, as well as the hypothesis of direct injection of $\mathrm{Cl}_{2}, \mathrm{HCl}$, and $\mathrm{H}_{2} \mathrm{O}$ into the stratosphere. A detailed discussion of these results is given. The most important use of these results is the constraints we can place on the possible global importance of heterogeneous chemistry in the lower stratosphere. 
TABLE 1. Comparison of Observations of Species After the El Chichon Eruption and Model Results

\begin{tabular}{|c|c|c|c|c|c|c|c|}
\hline \multirow[b]{2}{*}{ Species } & \multicolumn{3}{|c|}{ Observation } & \multicolumn{4}{|c|}{ Model } \\
\hline & Altitude, km & Change, \% & Reference & Altitude, $\mathbf{k m}$ & Case A, \% & Case B, \% & Case C, \% \\
\hline $\mathbf{O}_{3}$ & $\begin{array}{l}24-30 \\
25\end{array}$ & $\begin{array}{l}-6-10 \\
-4.6\end{array}$ & $\begin{array}{l}\text { Heath and Schlesinger } \\
\text { [1984] } \\
\text { Chandra [1987] }\end{array}$ & 24 & -3.0 & -7 & -12 \\
\hline \multirow[t]{2}{*}{$\mathrm{HCl}$} & 21.6-27.4 & $+30-40$ & $\begin{array}{l}\text { B. W. Gandrud and } \\
\text { A. L. Lazarus } \\
\text { (private communi- } \\
\text { cation, 1983) }\end{array}$ & 24 & +8 & +10 & +102 \\
\hline & $\begin{array}{l}\text { column } \\
\text { above } \\
12 \mathrm{~km}\end{array}$ & +40 & $\begin{array}{l}\text { Mankin and Coffey } \\
\text { [1984] }\end{array}$ & $\begin{array}{l}\text { column } \\
\text { above } \\
12 \mathrm{~km}\end{array}$ & +2.7 & +1.7 & +41 \\
\hline \multirow[t]{2}{*}{ NO } & 26 & $\sim-50$ & $\begin{array}{l}\text { McFarland et al. } \\
{[1986]}\end{array}$ & 26 & $\sim+4$ & $\sim+1$ & -44 \\
\hline & 30 & -75 & $\begin{array}{l}\text { Roscoe et al. } \\
\quad[1986]\end{array}$ & 30 & -2 & $-\mathbf{5}$ & -60 \\
\hline \multirow[t]{2}{*}{$\mathrm{NO}_{2}$} & & & $\begin{array}{l}\text { McFarland et al. } \\
{[1986]}\end{array}$ & 26 & -3.5 & -3 & -49 \\
\hline & $25-32$ & -50 & $\begin{array}{l}\text { Roscoe et al. } \\
\text { [1986] }\end{array}$ & & & & \\
\hline $\mathrm{NO}+\mathrm{NO}_{2}$ & $\begin{array}{l}\text { column } \\
\text { above } \\
12 \mathrm{~km}\end{array}$ & -50 & $\begin{array}{l}\text { Mankin and Coffey } \\
{[1986]}\end{array}$ & $\begin{array}{l}\text { column } \\
\text { above } \\
12 \mathrm{~km}\end{array}$ & -0.03 & -2.8 & -28 \\
\hline $\mathrm{NO}_{2} / \mathrm{NO}$ & 20.31 & (see text) & $\begin{array}{l}\text { McFarland et al. } \\
\quad[1986]\end{array}$ & (see text) & & & \\
\hline $\mathrm{HNO}_{3}$ & $\begin{array}{l}\text { column } \\
\text { above } \\
12 \mathrm{~km}\end{array}$ & $\sim 0$ & $\begin{array}{l}\text { Mankin and Coffey } \\
{[1986]}\end{array}$ & $\begin{array}{l}\text { column } \\
\text { above } \\
12 \mathrm{~km}\end{array}$ & +0.5 & -2.9 & -25 \\
\hline OH & $\begin{array}{l}\text { column } \\
\text { above } \\
0 \mathrm{~km}\end{array}$ & +35 & $\begin{array}{l}\text { Burnett and Burnett } \\
\text { [1984] }\end{array}$ & $\begin{array}{l}\text { column } \\
\text { above } \\
0 \mathrm{~km}\end{array}$ & -0.1 & -0.8 & +6 \\
\hline
\end{tabular}

Case A, model calculations including only the perturbation of the radiation field; case B, case A with the additional effects of the temperature perturbation; case C, case B with the inclusion of heterogeneous reaction (H1) $\mathrm{ClNO}_{3} \rightarrow \mathrm{HCl}$. All model results for $20^{\circ} \mathrm{N}, 1400$ LT (solar zenith angle of $45^{\circ}$ ).

\section{Radiative Transfer}

Our radiative transfer model treats the attenuation of the solar beam using spherical geometry, while the multiple scattering is evaluated for an inhomogeneous, plane parallel atmosphere. For details, see D. V. Michelangeli et al. (manuscript in preparation, 1989); an earlier version of this radiation model was described by Gladstone [1982] and Froidevaux et al. [1985]. In the model, the direct solar beam is attenuated by Rayleigh scattering by $\mathrm{N}_{2}$ and $\mathrm{O}_{2}$ and $\mathrm{ab}-$ sorption by $\mathrm{O}_{3}, \mathrm{O}_{2}$, and $\mathrm{NO}_{2}$. The total actinic flux is the sum of the direct flux and the diffuse flux (due to multiple scattering and integrated over $4 \pi$ steradians). The calculations were performed for solar zenith angles between 0 and $89^{\circ}$, wavelengths from 1750 to $8000 \AA$, and altitudes from 0 to $50 \mathrm{~km}$. A Lambert surface with an albedo of 0.25 was prescribed at the lower boundary. The sulfuric acid aerosols were added to the model as scatterers of the radiation.

The optical properties of the aerosols are taken from the calculations of Pollack and Ackerman [1983], which compared well with the observational data of Knollenberg and Huffman [1983] and Clarke et al. [1983]. The average single scattering albedo (0.99), and the asymmetry factor $(g=0.7)$ for the Henyey-Greenstein phase function (for definitions, see Van de Hulst [1980] and Hansen and Travis [1974]), are independent of wavelength. The particle extinction cross section ranges from $1.8 \times 10^{-8} \mathrm{~cm}^{2}$ at $8000 \AA$ to $1.4 \times 10^{-8}$ $\mathrm{cm}^{2}$ for wavelengths $\leq 2560 \AA$. From the total "dust" optical depth as a function of wavelength recorded in JuneJuly, at Mauna Loa in Hawaii $\left(20^{\circ} \mathrm{N}\right.$ ) (Figure 3 of DeLuisi et al. [1983]) and the backscattering ratio obtained by lidar sounding (Figure 1 of DeLuisi et al. [1983]), we obtain the vertical distribution of the optical depth change that is due to volcanic aerosol loading as a function of wavelength. The aerosols are distributed between 16 and $30 \mathrm{~km}$, and the largest increase in optical depth was between 27 and $29 \mathrm{~km}$ ( $40 \%$ of total optical depth due to aerosol scattering). The sharp gradient near $30 \mathrm{~km}$ seems to be real, since it was also observed by Shibata et al. [1984]. Their radar measurements extend up to $32 \mathrm{~km}$ and show a clear drop off of the scattering ratio at those high altitudes.

In a "clear" atmosphere (no aerosol scattering), there is little direct flux shortward of $3000 \AA$ and below $30 \mathrm{~km}$. This is mainly due to the extremely high absorption cross section of $\mathrm{O}_{3}$ (Hartley bands from 2000 to $3000 \AA$ ) and $\mathrm{O}_{2}$ (Schumann-Runge and Herzberg bands shortward $2000 \AA$ ) [Liou, 1980]. In the regions of particularly large absorptions (by $\mathrm{O}_{2}$ below $2000 \AA$ and by $\mathrm{O}_{3}$ at $2500 \AA$ ) the direct 
flux is zero and does not change when the aerosols are included (Figure 1a). These represent the dotted regions in Figure 1a. The aerosols scatter the photons out of the direct beam, attenuating the radiation by as much as $30 \%$ (Figures $1 a$ and $1 b$ ). The small-scale structure in the percent changes with altitude shortward of $\sim 2850 \AA$ are due to numerical noise, caused by taking differences of small direct flux values. Longward of $3000 \AA$, there is a smooth variation with altitude, as expected (Figure $1 b$ ). From $3000 \AA$ to $8000 \AA$, the extinction cross section of the aerosols increases from 1.4 to $1.8 \times 10^{-8} \mathrm{~cm}^{2}$, which causes larger decreases in the direct flux at longer wavelengths (Figure 1b).
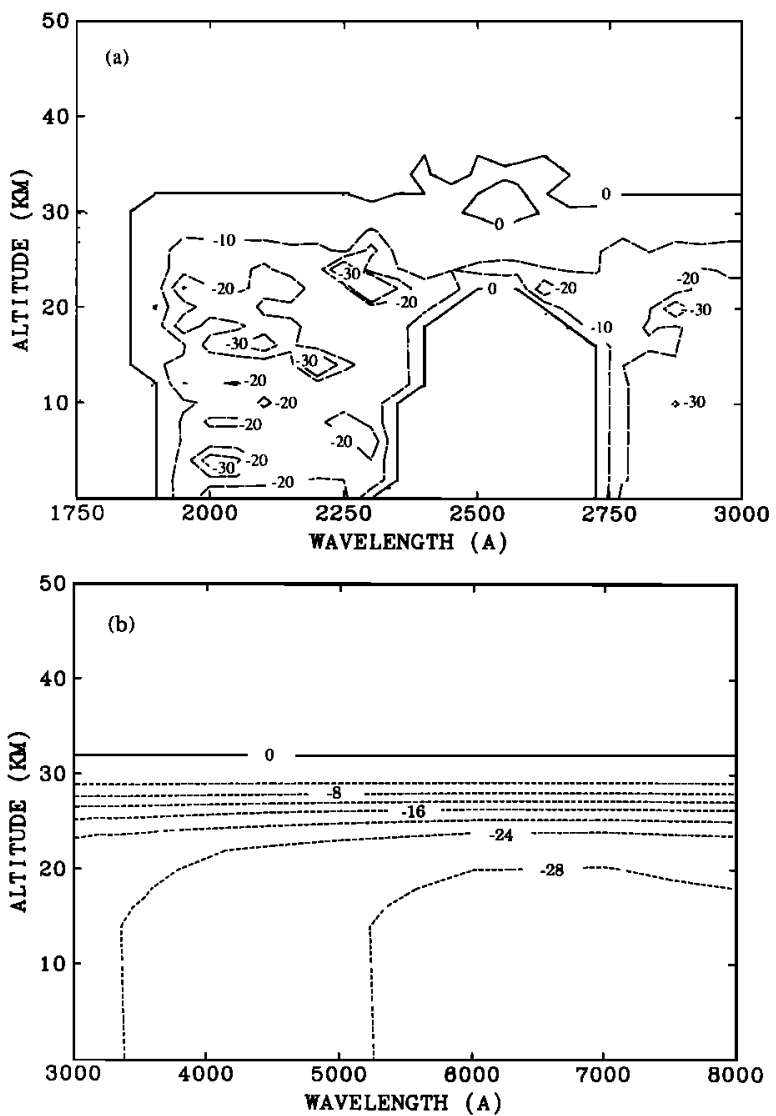

Fig. 1. The percent difference in the direct flux as a function of altitude (in kilometers) for a solar zenith angle of $45^{\circ}$, where the percent difference in a quantity $X$ is defined as $\left[\left(X_{\text {aerosols }}-X_{\text {no aerosols }}\right) / X_{\text {no aerosols }}\right] \times 100$. The shaded areas represent regions of zero flux in the "no aerosol" case. (a) For wavelengths from 1750 to $3000 \AA$. (b) For wavelengths from 3000 to $8000 \AA$.

The aerosols, being nearly white scatterers, increase the diffuse actinic flux at wavelengths longer than $2750 \AA$ and, in the window of the $\mathrm{O}_{2}$ absorption, between 2000 and $2250 \AA$ (Figures $2 a$ and $2 b$ ). The largest change ( $>100 \%$ ) was obtained within the aerosol layer. Shortward of $3000 \AA$, the increases are particularly large because of the small flux values in the "clear" atmosphere. Also, a large enhancement in the diffuse flux is found at $8000 \AA$, where there is little gas absorption and where the dependence on the surface albedo is the largest. At $2500 \AA$ the diffuse flux decreases because the aerosols scatter the radiation in a way that increases the effective pathlength of the photons in a region of strong
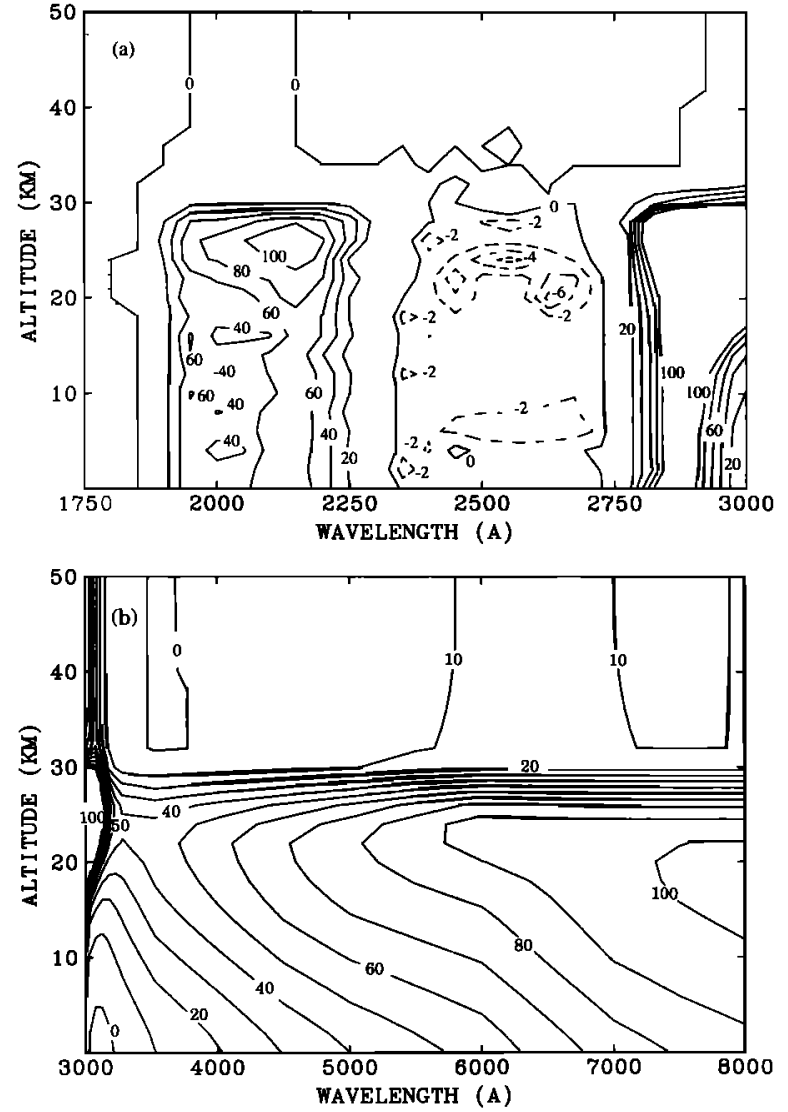

Fig. 2. The percent difference (as defined in Figure 1) in the diffuse flux as a function of altitude (kilometers) for a solar zenith angle of $45^{\circ}(a)$ for wavelengths from 1750 to $3000 \AA$ and (b) from 3000 to $8000 \AA$.

ozone absorption. Therefore the probability of absorption increases, so we observe a net loss of flux. The diffuse flux varies as a function of solar zenith angle in the way described by Luther and Gelinas [1976] and Froidevaux et al. [1985] for both clear and aerosol-containing cases. There is a smooth decrease in the diffuse flux with increasing angle. At $90^{\circ}$ solar zenith angle, the curves converge to near zero diffuse flux at the ground.

Between 20 and $30 \mathrm{~km}$, near $2000 \AA$ and $3000 \AA$, a slight decrease in total radiation is obtained, since the radiation field is dominated by the direct flux, which is very small (almost zero), but decreases slightly when the aerosols are added (Figure 3a). At $2500 \AA$ there is no direct flux; therefore the total radiation decrease reflects the change in the diffuse flux. Between $2750 \AA$ and $3000 \AA$ the radiation increases by as much as $80 \%$ because the diffuse flux increases by more than $100 \%$ and is the most important component of the total radiation. Longward of $4000 \AA$, where the total radiation increases by $8 \%$ within the aerosol layer, the diffuse flux is also the most important contributor to the radiation field. At $3000 \AA$ and $6000 \AA$ the direct $f u x$ is the largest component of the total radiation (as for $2000 \AA$ and $2500 \AA$ ), and therefore we observe a decrease in the total radiation at $3000 \AA$ and smaller increases at $6000 \AA$ (Figure $3 b$ ). This effect at $6000 \AA$ is caused by the $\mathrm{O}_{3}$ Chappuis bands and disappears on removal of the $\mathrm{O}_{3}$ Chappuis absorption. In this region of enhanced gas absorption, the increased aerosol scattering leads to a longer path length for each photon, 

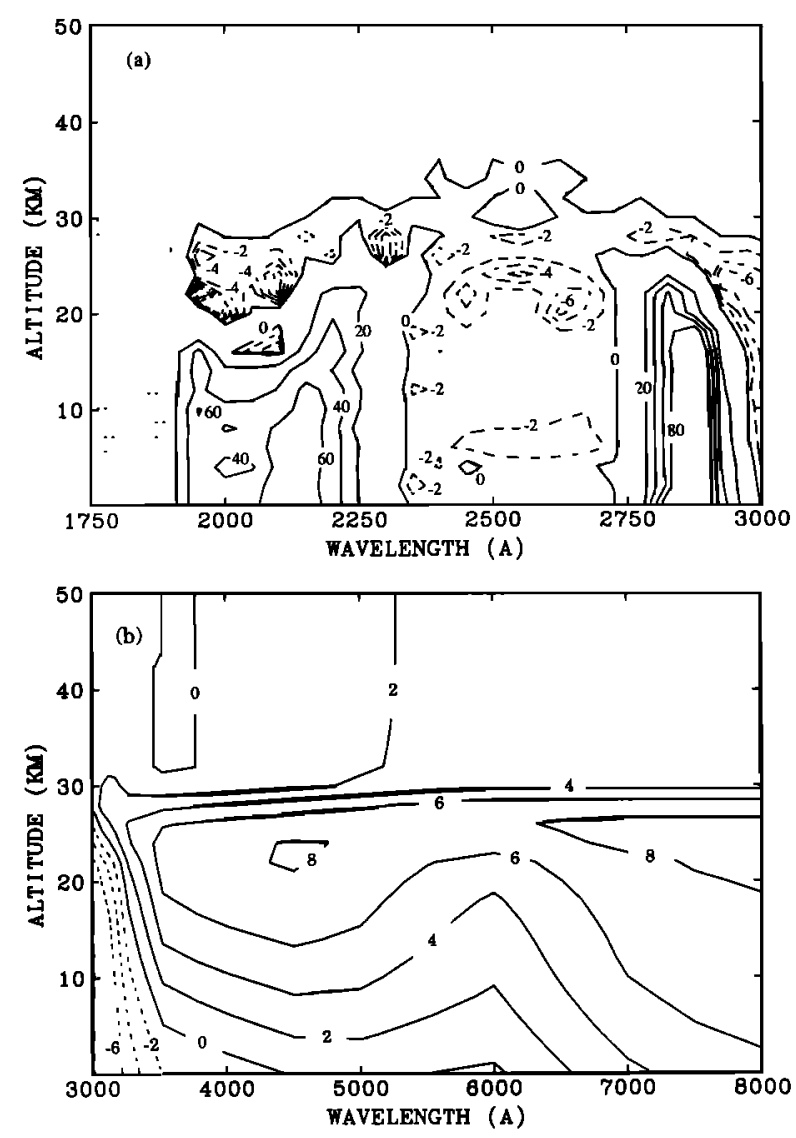

Fig. 3. The percent difference (as defined in Figure 1) in the total radiation as a function of altitude (kilometers) for a solar zenith angle of $45^{\circ}$ (a) for wavelengths from 1750 to $3000 \AA$ and (b) from 3000 to $8000 \AA$.

therefore leading to enhanced $\mathrm{O}_{3}$ Chappuis absorption of the diffuse radiation field. Above the aerosol layer, the total radiation increases by $2 \%$ because of the extra backscattering. Below the aerosol layer we obtain a few percent increase in the total radiation. This result is counter-intuitive, since we would expect the aerosols to decrease the total radiation at the ground. This effect is discussed further by D. V. Michelangeli et al. (manuscript in preparation, 1989). The calculations show that the presence of aerosols leads to a "trapping" of photons in the atmosphere.

Our radiation results are in good agreement with the observations of DeLuisi et al. [1983]. They measured with open-band and broad-band filters, a $5.6 \%$ decrease in the total radiation in the 0.3 to $3 \mu \mathrm{m}$ bands at noon with a pyranometer at Mauna Loa, in June-July 1982. This measurement corresponds to the irradiance (net flux through a surface), not to the actinic flux. At solar zenith angles of $0^{\circ}$ and integrating from 3000 to $8000 \AA$, weighted by the solar flux, we obtain a $2 \%$ irradiance decrease which agrees reasonably well with the observations, considering how difficult the interpretation of the measurement is. They also found that the direct flux alone had decreased by $21.3 \%$, which compares very well with our $21 \%$ decrease at $0^{\circ}$ solar zenith angle from 3000 to $8000 \AA$. Unfortunately, the observations do not exist at other solar zenith angles to permit further comparison.

The chemical and radiation field calculations were solved self-consistently. Runs of the photochemical and radiative models were iterated with computed $\mathrm{O}_{3}$ and $\mathrm{NO}_{2}$ profiles entered into radiative calculations and the consequent radiation field entered into the photochemical calculation. Upon comparing results from successive calculations, we found that there was less than a $1 \%$ difference in the radiation longward of $3000 \AA$.

\section{Photochemical Model}

We used the one-dimensional stratospheric chemistry model described by Froidevaux et al. [1985], in which chemical production and loss are coupled to transport, parameterized by an eddy diffusion coefficient. The rate constants used in the calculations are similar to those adopted by Froidevaux et al. [1985]. Tables $2 a$ and $2 b$ list the reactions with updated rate constants as well as other reactions referred to in the text of this paper. The boundary conditions are identical to those in Froidevaux et al. [1985]. A change to the 1985 model is the extension to $1750 \AA$ of the short wavelength cutoff for the inclusion of the diffuse radiation field.

The background model atmosphere used is that of the U.S. Standard Atmosphere 1976. The latitude $\left(20^{\circ} \mathrm{N}\right)$ and season (summer solstice) are chosen to correspond to the position and date of the aerosol observations used in our calculations and certain species measurements. The water vapor mixing ratio is fixed from 0 to $16 \mathrm{~km}$. All calculations are performed from 0 to $60 \mathrm{~km}$.

Most of the calculations were run to steady state in a diurnally varying radiation field, marched forward in time until convergence ( $<2 \%$ difference in concentrations from day to day) was achieved. The model results thus obtained for steady state differ by $<2 \%$ from calculations done explicitly for an elapsed time of 3 months, corresponding to the time period for most observations to be discussed.

Five basic cases shall be considered, starting with a standard, clear steady state atmosphere, to which we compare all other calculations. The second case considers the radiative effects of the aerosols, while the third case investigates the combined effects of the radiation change and temperature variation within the aerosol layer, as calculated by Pollack and Ackerman [1983] (which matched the observations of Labitzke et al. [1983] and Quiroz [1983]). The temperature change ranges from $+0.9^{\circ} \mathrm{C}$ at $14 \mathrm{~km}$, to $+3.2^{\circ} \mathrm{C}$ at $24 \mathrm{~km}$, and to $-3.1^{\circ} \mathrm{C}$ at $38 \mathrm{~km}$, above which the temperature did not change. The decrease above $30 \mathrm{~km}$ is probably an overestimate of the change in temperature. Because of the lack

TABLE 2a. Partial List of Photochemical Reactions

\begin{tabular}{cc}
\hline Reaction Number & Reaction \\
\hline 3 & $\mathrm{O}_{3}+\mathrm{h} \nu \rightarrow \mathrm{O}_{2}+\mathrm{O}$ \\
4 & $\mathrm{O}_{3}+\mathrm{h} \nu \rightarrow \mathrm{O}_{2}+\mathrm{O}\left({ }^{1} D\right)$ \\
6 & $\mathrm{H}_{2} \mathrm{O}_{2}+\mathrm{h} \nu \rightarrow 2 \mathrm{OH}$ \\
8 & $\mathrm{NO}+\mathrm{h} \nu \rightarrow \mathrm{N}+\mathrm{O}$ \\
9 & $\mathrm{NO}_{2}+\mathrm{h} \nu \rightarrow \mathrm{NO}+\mathrm{O}$ \\
10 & $\mathrm{NO}_{3}+\mathrm{h} \nu \rightarrow \mathrm{NO}_{2}+\mathrm{O}$ \\
11 & $\mathrm{NO}_{3}+\mathrm{h} \nu \rightarrow \mathrm{NO}+\mathrm{O}_{2}$ \\
12 & $\mathrm{~N}_{2} \mathrm{O}_{5}+\mathrm{h} \nu \rightarrow 2 \mathrm{NO}_{2}+\mathrm{O}$ \\
13 & $\mathrm{HNO}_{3}+\mathrm{h} \nu \rightarrow \mathrm{NO}_{2}+\mathrm{OH}$ \\
23 & $\mathrm{ClNO}_{3}+\mathrm{h} \nu \rightarrow \mathrm{Cl}+\mathrm{NO}$ \\
24 & $\mathrm{HOCl}_{3} \mathrm{~h} \nu \rightarrow \mathrm{OH}+\mathrm{Cl}$ \\
25 & $\mathrm{ClO}+\mathrm{h} \nu \rightarrow \mathrm{Cl}+\mathrm{O}$ \\
26 & $\mathrm{HCl}+\mathrm{h} \nu \rightarrow \mathrm{H}+\mathrm{Cl}$ \\
\hline
\end{tabular}

All reaction numbers and cross-section references correspond to those in Table $1 b$ in Froidevaux et al. [1985]. 
TABLE 2b. Partial List of Chemical Reactions

\begin{tabular}{|c|c|}
\hline Reaction Number & Reaction \\
\hline $\begin{array}{c}1 \\
2 \\
6 \\
10 \\
17 \\
18 \\
19 \\
29 \\
32 \\
33 \\
34 \\
35 \\
38 \\
40 \\
45 \\
46 \\
47 \\
48 \\
54 \\
55 \\
56 \\
57 \\
58 \\
60 \\
61 \\
68 \\
74 \\
77 \\
84 \\
88 \\
89\end{array}$ & 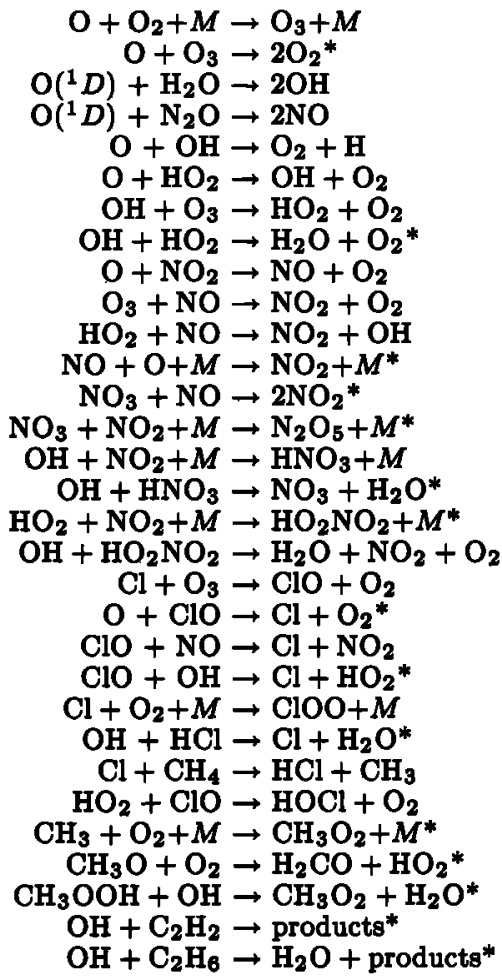 \\
\hline
\end{tabular}

All reaction numbers correspond to those in Table $1 a$ of Froidevause et al. [1985].

- Reactions for which the rate constants have been updated using the values from DeMore et al. [1985], while all others were taken from Froidevaux et al. [1985].

of data in this region, we should not put too much importance on the results above $30 \mathrm{~km}$. Our results show that the temperature change has a significant effect. There are substantial differences in the percent changes for the species whose concentrations are primarily determined by nonphotolytic processes.

Two additional, speculative scenarios are also modeled. In one, we simulate the injections of $\mathrm{Cl}_{2}, \mathrm{HCl}$, or $\mathrm{H}_{2} \mathrm{O}$. In this case, the calculations were run for an elapsed time of specifically 3 months, since in a steady state calculation, material introduced in a one-time injection "washes out." In the other speculative scenario, effects of potential heterogeneous chemistry on aerosols are modeled. Because of the uncertainty in the actual physics of each of these cases, calculations with a diurnally averaged radiation field were felt to be adequate, except for our "best" case, which was run in a full diurnal mode. Also, these calculations were carried out for only 3 months of model time to minimize problems of mass loss due to absorption of gases by the aerosols.

An important issue in doing these calculations is the question of whether or not a one-dimensional, zonally averaged representation of the atmosphere can be validly used in the proposed simulations. We have compared our calculations with observations 3 months after the eruption. In this region of the stratosphere the mixing time scale from equator to pole is about 4-6 months [Rosenfield et al., 1987]. The Solar Mesosphere Explorer satellite measurements of Barth et al. [1983] showed that 3 weeks after the El Chichon eruption, the aerosol cloud extended from 0 to $30^{\circ} \mathrm{N}$, and remained confined to that latitude region until at least June of 1982. This observation suggests that there was little meridional transport at that season, so therefore we feel our one-dimensional model can be a valid representation of atmospheric processes for the first 3 months after the eruption. As for the possible error in the absolute abundances of long-lived, transport dependent species such as $\mathrm{CH}_{4}$ and $\mathrm{NO}_{y}$, it is minimized, since we are only interested in the relative changes in the species concentrations, and report no absolute values.

\section{Results of Photochemical Calculations WITH MODIFIED RADIATION FIELD AND Temperature Perturbation}

\subsection{Photodissociation Rates}

The diffuse actinic fluxes obtained from the detailed radiative transfer calculations with the aerosols present are entered into the photochemical model. The change in radiation field because of these aerosols affects the photodissociation coefficients ( $J$ values), causing them to increase by as much as $10 \%$ or to decrease by $15 \%$ for species absorbing strongly in regions where the total actinic radiation increases and decreases, respectively. The response to the change in the radiation field varies from species to species. All photodissociation rate constants that changed by more than $1 \%$ are reported in Figures $4 a-4 c$. The species whose peak absorption cross section is between 2000 and $3000 \AA$ $\left(\mathrm{O}_{2}, \mathrm{H}_{2} \mathrm{O}, \mathrm{NO}, \mathrm{HNO}_{3}, \mathrm{HCl}\right)$ have decreasing photodissociation rate constants. More specifically, $\mathrm{O}_{2}, \mathrm{NO}$, and $\mathrm{H}_{2} \mathrm{O}$ have large absorption cross sections shortward of $2000 \AA$, and $\mathrm{HCl}$ absorbs shortward of $2300 \AA$, where the total radiation decreases by a maximum of $15 \%$ between 15 and $30 \mathrm{~km}$ (see Figure $3 a$ ). In these cases, the photodissociation rate constants decrease by up to $15 \%$ from 15 to $30 \mathrm{~km}$ (Figures $4 a-4 c$ ). For $\mathrm{HNO}_{3}$ the absorption ranges from 1900 to $3275 \AA$, covering a wide wavelength region of inereasing and decreasing total radiation (Figures $3 a$ and $3 b$ ). Therefore the decrease in the photodissociation rate constant is only $7 \%$ (Figure $4 b$ ).

In Figures $4 a-4 c$ we can see clearly that the largest increase in the photodissociation coefficients occurs for the species with the largest absorption cross sections between 3000 and $8000 \AA$. The absorption cross section of $\mathrm{NO}_{2}$ peaks at $7 \times 10^{-19} \mathrm{~cm}^{2}$ near $4000 \AA$, and that of $\mathrm{ClNO}_{3}$ is large $\left(10^{-22}-10^{-19} \mathrm{~cm}^{2}\right)$ between 3000 and $4500 \AA$. $\mathrm{N}_{2} \mathrm{O}_{5}$ absorbs strongly up to $3825 \AA$. These species are the most affected by any change in the radiation between 3000 and $4000 \AA$ (see Figures $4 b$ and $4 c$ ). The photodissociation rate constants of all these species increase up to $10 \% . \mathrm{O}_{3}$ (Chappuis bands) and $\mathrm{NO}_{3}$, whose peak cross section $\left(4.9 \times 10^{-18} \mathrm{~cm}^{2}\right)$ occurs at $5900 \AA$, are sensitive to a variation in the radiation field, between 4000 and $8000 \AA$ (see Figures $4 a$ and $4 b$ ). The same is true for $\mathrm{HOCl}$, whose absorption extends out to $4200 \AA$ (Figure 4c). $\mathrm{ClO}$ and $\mathrm{H}_{2} \mathrm{O}_{2}$ dissociate below $3425 \AA$ and $3525 \AA$, respectively, and will be only slightly affected by the change in the flux in the visible region of the spectrum; therefore the photodissociation rate constants change only a little (Figures $4 a$ and $4 c$ ).

In contrast with our large change in the $\mathrm{O}_{3}$ photodissociation rate constant, Adriani et al. [1987] obtained a $1 \%$ increase at $20^{\circ} \mathrm{N}$. This small change is due to the fact that the aerosol data used were taken in December 1982, 9 months 

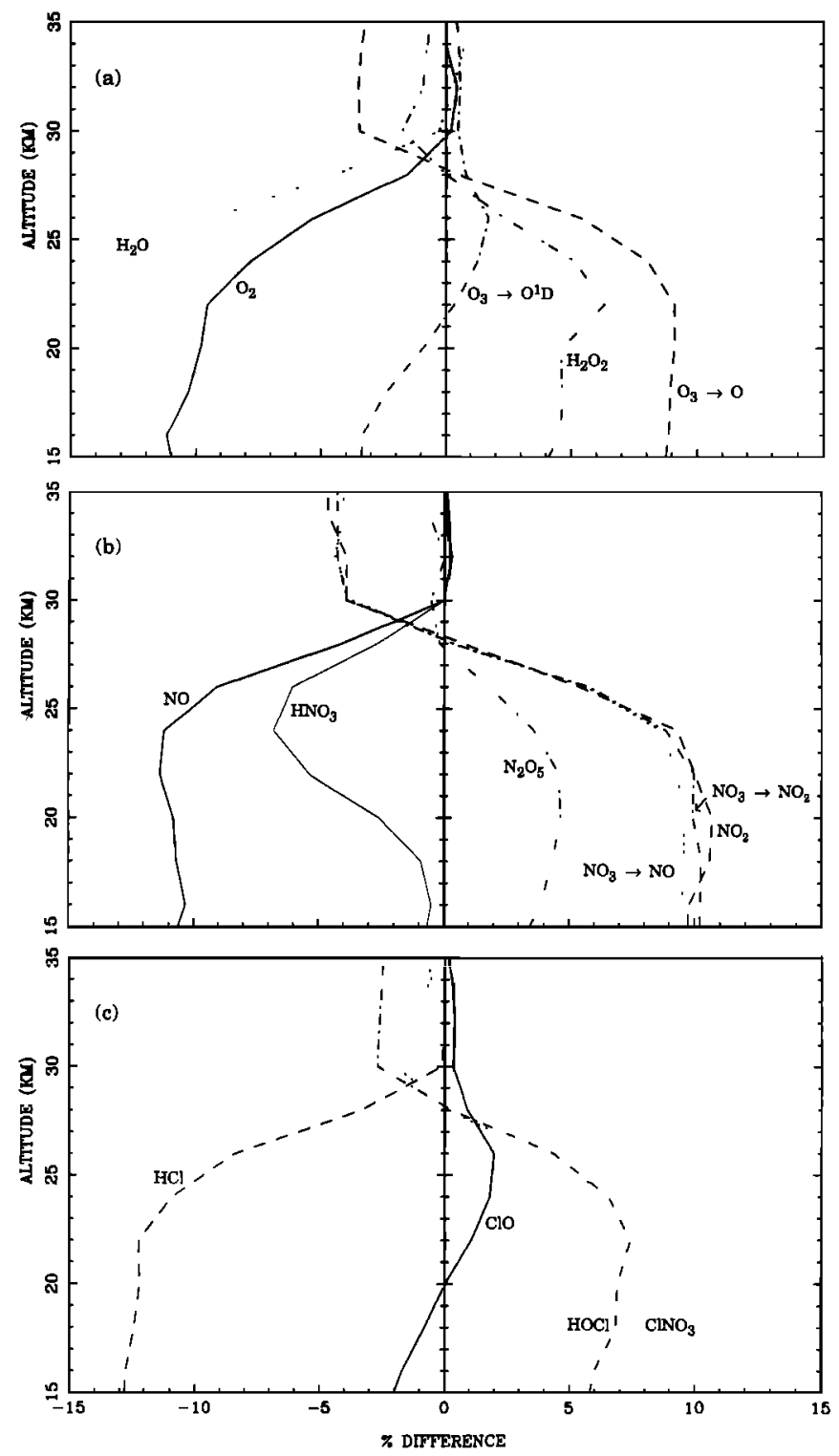

Fig. 4. The percent difference (as defined in Figure 1) in the photodissociation rate constants at a solar zenith angle of $45^{\circ}$ for (a) $\mathrm{O}_{2}, \mathrm{H}_{2} \mathrm{O}, \mathrm{H}_{2} \mathrm{O}_{2}$, and $\mathrm{O}_{3}$; (b) $\mathrm{NO}, \mathrm{NO}_{2}, \mathrm{HNO}_{3}, \mathrm{~N}_{2} \mathrm{O}_{5}$, and $\mathrm{NO}_{3}$; and (c) $\mathrm{HCl}, \mathrm{ClO}, \mathrm{HOCl}$, and $\mathrm{ClNO}_{3}$.

after the eruption, when the optical depth had decreased substantially because of coagulation and gravitational settling of the aerosols.

\subsection{Concentration Changes}

The changes in photodissociation rate constants lead to changes in the abundances of certain molecules. While changes in column abundances between 0 and $60 \mathrm{~km}$ were small, when we focus our attention on specific altitude levels, in particular within the aerosol layer, larger variations are seen (Figures 5-10). It is important to keep in mind that changes smaller than $2 \%$ are insignificant, owing to the fact that the threshold for diurnal convergence was $2 \%$. We choose to report the concentration results at $1400 \mathrm{LT}$ (solar zenith angle of $45^{\circ}$ ), corresponding to the figures illustrating changes in the radiation field (Figures 1, 2, and 3). The combination of radiative and thermal perturbations enables us to understand the changes in $\mathrm{O}_{3}$, but cannot quantitatively

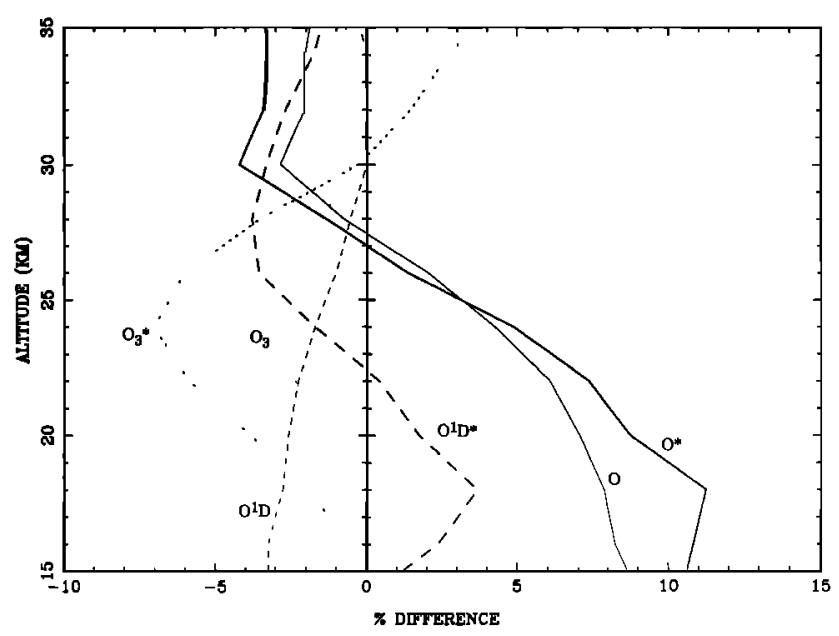

Fig. 5. The percent difference (as defined in Figure 1) in the concentrations of $\mathrm{O},\left(\mathrm{O}\left({ }^{1} D\right)\right), \mathrm{O}_{3}$ at $20^{\circ} \mathrm{N}$ for a local time of 1400 (solar zenith angle of $45^{\circ}$ ). The curves identified by an asterisk represent the results when the temperature perturbation was added to the radiation change.

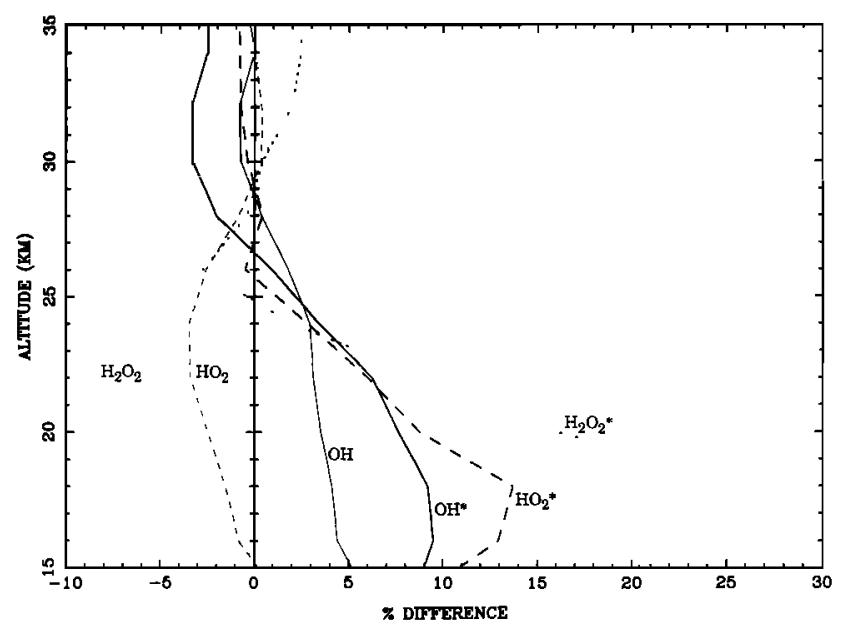

Fig. 6. The percent difference in the concentrations of $\mathrm{OH}, \mathrm{HO}_{2}$, $\mathrm{H}_{2} \mathrm{O}_{2}$ under the conditions described in Figure 5.

account for the other observed changes. In the following we describe the comparison between theory and data in detail. It is important to bear in mind that the purpose of modeling is not only to forge agreement between theory and experiment but also to provide insight into the physics and chemistry of the system. This in turn can lead us to explore new ideas and test new hypotheses.

$\mathrm{O}_{x}$. The ultimate source of $\mathrm{O}_{x}\left(\mathrm{O}+\mathrm{O}_{3}\right)$ is $\mathrm{O}_{2}$ photodissociation. The principal reactions resulting in the loss of $\mathrm{O}_{x}$ are

$$
\begin{aligned}
\mathrm{O}+\mathrm{O}_{3} & \rightarrow 2 \mathrm{O}_{2} \\
\mathrm{O}+\mathrm{OH} & \rightarrow \mathrm{H}+\mathrm{O}_{2} \\
\mathrm{O}+\mathrm{HO}_{2} & \rightarrow \mathrm{OH}+\mathrm{O}_{2} \\
\mathrm{O}+\mathrm{NO}_{2} & \rightarrow \mathrm{NO}+\mathrm{O}_{2} \\
\mathrm{O}+\mathrm{ClO} & \rightarrow \mathrm{O}_{2}+\mathrm{Cl}
\end{aligned}
$$

(the reaction numbers refer to the listing in Tables $2 a$ and $2 b$ ). Hence the loss of $\mathrm{O}_{x}$ by these reactions is proportional to the atomic $\mathrm{O}$ abundance. 


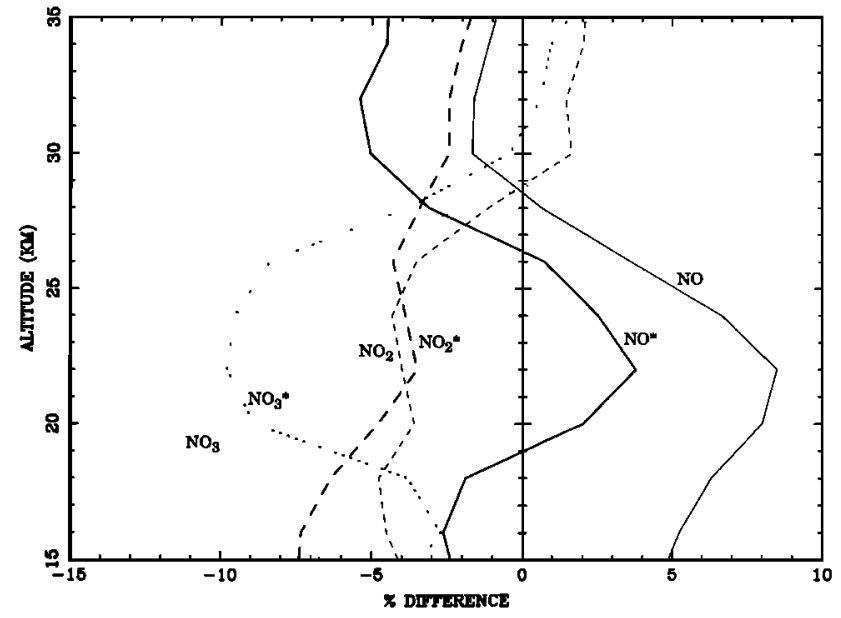

Fig. 7. The percent difference in the concentrations of $\mathrm{NO}, \mathrm{NO}_{2}$, $\mathrm{NO}_{3}$ under the conditions described in Figure 5.

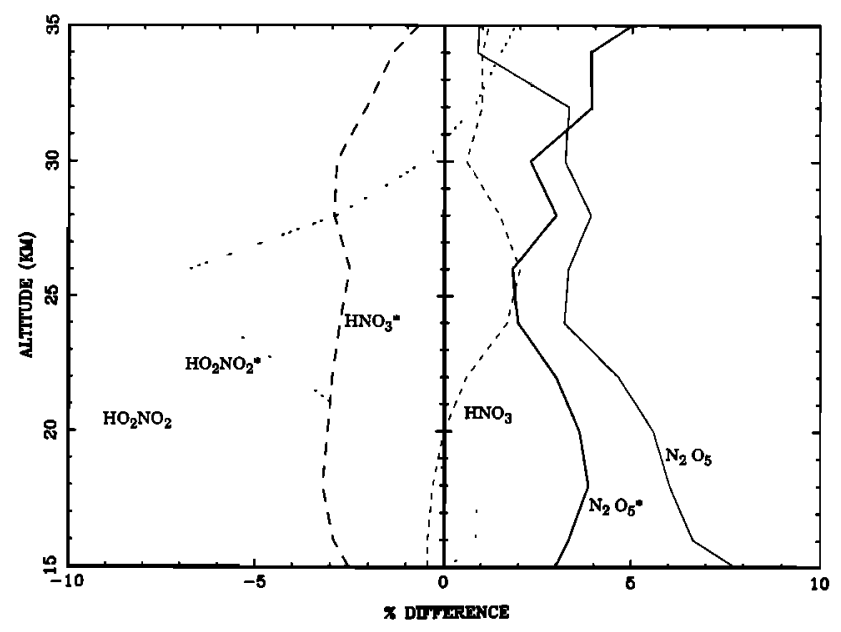

Fig. 8. The percent difference in the concentrations of $\mathrm{N}_{2} \mathrm{O}_{5}$, $\mathrm{HNO}_{3}, \mathrm{HO}_{2} \mathrm{NO}_{2}$ under the conditions described in Figure 5.

Ozone, the predominant form of $O_{x}$ in the stratosphere, decreases because both the source of $\mathrm{O}_{x}$ decreases and loss of $\mathrm{O}_{x}$ increases: (1) at $26 \mathrm{~km}$ there is a $\sim 6 \%$ decrease in the photodissociation rate constant of $\mathrm{O}_{2}$ due to the attenuation of radiation by the aerosols (Figure 4a); (2) the partitioning between $\mathrm{O}$ and $\mathrm{O}_{3}$ is governed by the rate of $\mathrm{O}_{3}$ formation via (R1),

$$
\mathrm{O}+\mathrm{O}_{2}+M \rightarrow \mathrm{O}_{3}+M
$$

and $\mathrm{O}_{3}$ loss through photodissociation,

(R3) and (R4)

$$
\mathrm{O}_{3}+\mathrm{h} \nu \rightarrow \mathrm{O}+\mathrm{O}_{2}
$$

yielding the steady state expression

$$
\frac{[\mathrm{O}]}{\left[\mathrm{O}_{3}\right]}=\frac{J_{3}+J_{4}}{k_{1}\left[\mathrm{O}_{2}\right][M]}
$$

The $[\mathrm{O}] /\left[\mathrm{O}_{3}\right]$ ratio increases by $3.5 \%$ at $26 \mathrm{~km}$ (at $1400 \mathrm{LT}$ ) because $J_{3}+J_{4}$ increases by this amount.

Adding to our model the perturbation of a few degrees

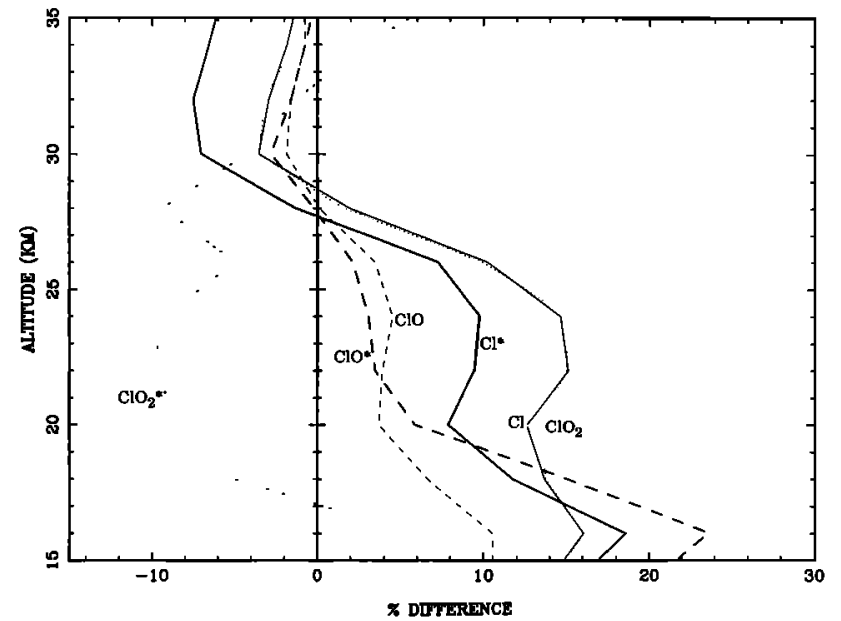

Fig. 9. The percent difference in the concentrations of $\mathrm{Cl}, \mathrm{ClO}$, $\mathrm{ClO}_{2}$ under the conditions described in Figure 5.

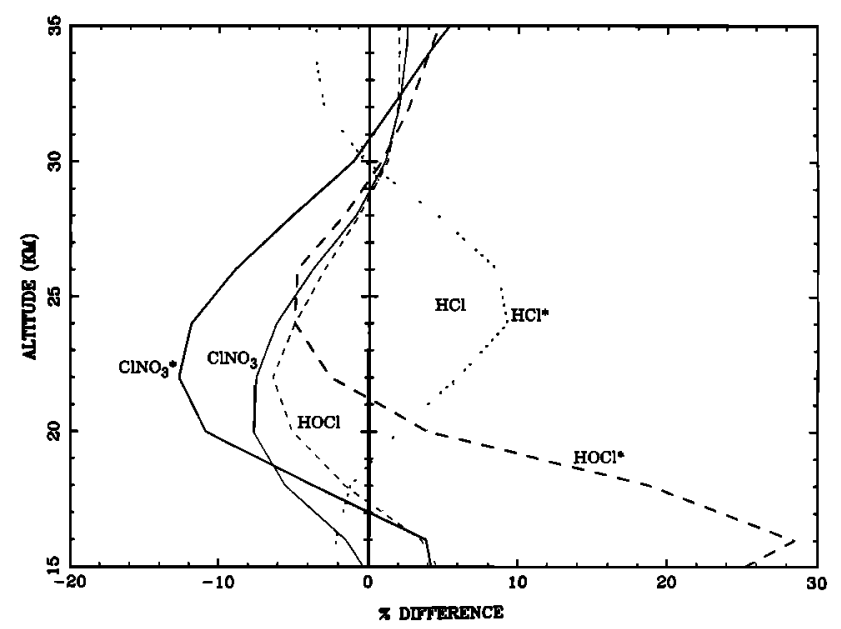

Fig. 10. The percent difference in the concentrations of $\mathrm{HCl}$, $\mathrm{HOCl}, \mathrm{ClNO}_{3}$ under the conditions described in Figure 5.

increase in stratospheric temperature leads to a decrease in the three-body $\mathrm{O}_{3}$-forming recombination rate constant $\left(k_{1}\right)$ due to its negative temperature dependence. Consequently, the $[\mathrm{O}] /\left[\mathrm{O}_{3}\right]$ ratio increases even more $(7 \%)$. This agrees with the results of Adriani et al. [1987], who also conclude that a small temperature perturbation will increase the ozone repartitioning. Increasing the stratospheric temperature by a few degrees also increased the rate constant for the reaction

$$
\mathrm{O}+\mathrm{O}_{3} \rightarrow 2 \mathrm{O}_{2}
$$

by $8 \%$, leading to a $3.5 \%$ increase in the rate of $\mathrm{O}_{x}$ destruction. As shown in Figure 5, $\mathrm{O}_{x}$ (mostly $\mathrm{O}_{3}$ ) decreased by $\sim 3 \%$ due to radiative perturbation alone, and by $\sim 7 \%$ due to the combined radiative and thermal perturbations at $26 \mathrm{~km}$.

Analyzing data from the Solar Backscatter Ultraviolet experiment (SBUV), Heath and Schlesinger [1984] and Chandra [1987] reported a few percent decrease in $\mathrm{O}_{3}$ concentration in the stratosphere at $20^{\circ} \mathrm{N}$ in June-July 1982 (see Table 2). Chandra [1987] also presented results of a 2-3\% decrease at 
higher latitudes $\left(50^{\circ} \mathrm{N}\right)$, which he compared with Dobson measurements and theoretical calculations by Adriani et al. [1987]. From analyses of Umkher data from an Hawaiian station, Komhyr et al. [1985] and DeLuisi et al. [1985] reported an ozone decrease near $25 \mathrm{~km}$.

Unfortunately, the evidence for an ozone depletion after the eruption is not completely convincing. Both Heath and Schlesinger [1984] and Chandra [1987] discuss the uncertainty resulting from the contribution of the aerosol scattering to their SBUV signal. A comparison of SME (Solar Mesospheric Explorer) and SBUV radiances led T. Clancy (private communication, 1988) to suggest that ozone increased above $35 \mathrm{~km}$, contrary to the assessment of Chandra [1987]. It is also crucial to determine the effect of the quasi-biennial oscillation (QBO) [e.g., Mantis et al., 1986]. Komhyr et al. [1985] believe this to be the main cause for their observed ozone decrease. However, Angell et al. [1985] show that the ozone reduction was greater than expected from QBO variations. More recently, Angell [1988] shows that there is no decrease in the tropical total ozone values correlated with the El Chichon eruption. However, the $\mathrm{O}_{3}$ decrease discussed in this paper is limited to the lowest 1.5 scale heights of the stratosphere, which would not noticeably affect the total ozone values, especially with the predicted increase in $\mathrm{O}_{3}$ in the middle stratosphere. Indeed, it seems clear from the correlation between aerosol maximum and ozone depletion [Bais et al., 1985] that a volcanic effect is present. Therefore the few percent decrease in ozone between 25 and $30 \mathrm{~km}$ at $20^{\circ} \mathrm{N}$ in June-July 1982 seems to be a believable consequence of the volcanic perturbation to the stratosphere.

Our estimates of the ozone concentration changes due to the presence of enhanced stratospheric aerosols are, at $26 \mathrm{~km}$, a 3.5\% decrease with the new radiation field and a 7.0\% decrease with the temperature perturbation. Above $30 \mathrm{~km}$, we obtain an increase in ozone, which agrees qualitatively with the observations of T. Clancy (private communication, 1988). It is clear that our model can reproduce the observed $\mathrm{O}_{3}$ change by simply including the change in the radiation field due to the presence of the aerosols, and the temperature change resulting from this presence, both changes in the atmosphere having been observed.

$\mathrm{HO}_{x}$. As can be seen from Figure 5, the $\mathrm{O}_{3}$ decrease produces lower $\mathrm{O}\left({ }^{1} D\right)$ concentrations, because $\mathrm{O}\left({ }^{1} D\right)$ is a product of ozone photolysis. Also, the higher temperatures decrease the quenching of $\mathrm{O}\left({ }^{1} D\right)$ by $\mathrm{N}_{2}$ and $\mathrm{O}_{2}$, tending to increase $O\left({ }^{1} D\right)$ concentrations.

The total $\mathrm{HO}_{x}\left([\mathrm{OH}]+\left[\mathrm{HO}_{2}\right]\right)$ decreases slightly at $26 \mathrm{~km}$ (Figure 6) because of the decrease in $O\left({ }^{1} D\right)$. When the temperature increases, the increase in $\mathrm{O}\left({ }^{1} D\right)$ below $22 \mathrm{~km}$ causes $\mathrm{HO}_{x}$ to change in the same way (13\% increase at $18 \mathrm{~km})$.

The destruction of $\mathrm{HO}_{x}$ is dominated by

$$
\begin{gathered}
\mathrm{OH}+\mathrm{NO}_{2}+M \rightarrow \mathrm{HNO}_{3}+M \\
\mathrm{HO}_{2}+\mathrm{NO}_{2}+M \rightarrow \mathrm{HO}_{2} \mathrm{NO}_{2}+M
\end{gathered}
$$

followed rapidly by

$$
\begin{gathered}
\mathrm{OH}+\mathrm{HNO}_{3} \rightarrow \mathrm{NO}_{3}+\mathrm{H}_{2} \mathrm{O} \\
\mathrm{OH}+\mathrm{HO}_{2} \mathrm{NO}_{2} \rightarrow \mathrm{NO}_{2}+\mathrm{H}_{2} \mathrm{O}+\mathrm{O}_{2}
\end{gathered}
$$

at $18 \mathrm{~km}$. At $26 \mathrm{~km}$,

$$
\mathrm{OH}+\mathrm{HO}_{2} \rightarrow \mathrm{H}_{2} \mathrm{O}+\mathrm{O}_{2}
$$

dominates the loss process for $\mathrm{HO}_{x}$. In these cases, the rates of the reactions (R46), (R48), and (R29) do not change significantly when the temperature perturbation is added. Therefore these loss reactions have little impact on the $\mathrm{HO}_{x}$ concentrations, which are controlled by the change in $\mathrm{O}\left({ }^{1} D\right)$.

The $5 \%$ decrease of $\mathrm{H}_{2} \mathrm{O}_{2}$ is due to the $5 \%$ increase in its photodissociation rate constant (Figure 4a), while its large $25 \%$ increase on inclusion of the temperature perturbation is caused by the $25 \%$ increase in the formation through disproportionation reaction between two $\mathrm{HO}_{2}$ molecules, as a consequence of the $\mathrm{HO}_{2}$ increase.

The $\mathrm{HO}_{x}$ partitioning is given by the $[\mathrm{OH}] /\left[\mathrm{HO}_{2}\right]$ ratio, which depends on (R20) and (R34) (loss of $\mathrm{HO}_{2}$ ) and (R19) and (R45) (loss of $\mathrm{OH}$ ) at $26 \mathrm{~km}$. This ratio increases by 4.6\% without the temperature perturbation, because of the [NO] increase and $\left[\mathrm{NO}_{2}\right]$ decrease of a few percent, to be discussed when investigating the $\mathrm{NO}_{x}$ changes below. When the temperature is increased by a few degrees, the overall effect is not to change the ratio significantly because of the combined effect on the rate constants. The concentration changes of specific $\mathrm{HO}_{x}$ species are in Figure 6.

Burnett and Burnett [1984] report a 30\% increase in the OH column abundance. Unfortunately, these ground-based measurements were taken at $40^{\circ} \mathrm{N}$ latitude, different from our $20^{\circ} \mathrm{N}$ latitude. C. R. Burnett and E. B. Burnett (private communication, 1986) have suggested that at $40^{\circ} \mathrm{N}$, they were located on the edge of the aerosol cloud, resulting in a "nonuniform" aerosol distribution and in "unusual" chemistry in that region. Our calculations do not show any change in the column abundance of $\mathrm{OH}$. We find a $6 \%$ increase at $24 \mathrm{~km}$. However, since the peak in the $\mathrm{OH}$ concentration is near $40 \mathrm{~km}$ and the concentration at $24 \mathrm{~km}$ is only a tenth of the peak value, the $6 \%$ change at $24 \mathrm{~km}$ will not affect the overall column abundance. Since the volcanic aerosol layer extended only up to $30 \mathrm{~km}$, any change at $40 \mathrm{~km}$ and above, which would affect the column, has to be due to another mechanism. Also counter to the observed OH column increase, McKeen et al. [1984] predicted that hydroxyl would not change. If we take into account the chemical changes that are due to the increase in $\mathrm{SO}_{2}$, as well as those caused by the optical depth changes, we do not see an explanation for the results of Burnett and Burnett [1984]. Adding the temperature effect does not significantly increase the $\mathrm{OH}$. Since $\mathrm{OH}$ in the lower stratosphere contributes so little to the column abundance, only an enormous perturbation of the lower stratospheric $\mathrm{HO}_{x}$ can result in a change in the column abundance.

$\mathbf{N O}, \mathbf{N O}_{2}$, and $\mathbf{H N O}_{3}$. The total $\mathrm{NO}_{x}\left([\mathrm{NO}]+\left[\mathrm{NO}_{2}\right]\right.$, with $\mathrm{NO}_{2}$ twice as abundant as $\mathrm{NO}$ ) decreases slightly, reflecting the $\mathrm{O}\left({ }^{1} D\right)$ decrease at $26 \mathrm{~km}\left[\mathrm{O}\left({ }^{1} D\right)+\mathrm{N}_{2} \mathrm{O}\right.$ is the source of $\mathrm{NO}_{x}$ ]. When the temperature perturbation is added, $\mathrm{NO}_{x}$ decreases by $\sim 3 \%$ at $26 \mathrm{~km}$, due to the $\mathrm{O}\left({ }^{1} D\right)$ decrease at that altitude.

The partitioning between $\mathrm{NO}$ and $\mathrm{NO}_{2}$ is given by the ratio

$$
\frac{\left[\mathrm{NO}_{2}\right]}{[\mathrm{NO}]}=\frac{k_{33}\left[\mathrm{O}_{3}\right]}{J_{9}+k_{32}[\mathrm{O}]}
$$


which decreases by $10.7 \%$ at $24 \mathrm{~km}$ (with only the inclusion of the radiation change). This is due to the $10 \%$ increase of $J_{9}$ and $[\mathrm{O}]$ as well as the lower $\left[\mathrm{O}_{3}\right]$ (Figure 5). The $k_{33}$ increases by $9.3 \%$ with the temperature perturbation, decreasing the $\left[\mathrm{NO}_{2}\right] /[\mathrm{NO}]$ ratio by $6 \%$.

Figure 7 shows the resulting changes in the concentrations of the individual $\mathrm{NO}_{x}$ species. $\mathrm{NO}, \mathrm{NO}_{2}$, and $\mathrm{NO}_{3}$ are directly affected by photodissociation changes. The increases in $J_{\mathrm{NO}_{2}}$ and $J_{\mathrm{NO}_{3}}$ (Figure $4 b$ ) decrease $\mathrm{NO}_{2}$ and $\mathrm{NO}_{3}$, while the opposite is true for NO.

The partitioning between $\mathrm{NO}_{x}$ and the reservoir $\mathrm{HNO}_{3}$ can be seen in the ratio

$$
\frac{\left[\mathrm{HNO}_{3}\right]}{\left[\mathrm{NO}_{2}\right]}=\frac{k_{45}[M][\mathrm{OH}]}{J_{13}+k_{46}[\mathrm{OH}]}
$$

which increases by $6 \%$ at $26 \mathrm{~km}$, because $\mathrm{HNO}_{3}$ photodissociation $\left(J_{13}\right)$ decreases by the same amount, while the other factors do not change at this altitude. The ratio only increases slightly by $2.2 \%$ when the temperature effect is added, because $\boldsymbol{k}_{45}$ (formation of $\mathrm{HNO}_{3}$ ) decreases by $2.4 \%$. Therefore $\mathrm{HNO}_{3}$ first increases due to its decreased photodissociation (Figure $4 b$ ) and then decreases with the temperature perturbation because of the decrease in its formation rate via (R45) (see Figure 8 for $\mathrm{HNO}_{3}$ concentration changes).

Observations show that $\mathrm{NO}_{x}$ decreased in the posteruption aerosol cloud. Roscoe et al. [1986] measured large NO and $\mathrm{NO}_{2}$ decreases after the eruption of $\mathrm{El} \mathrm{Chichon} \mathrm{above}$ $30 \mathrm{~km}$ (see Table 2). McFarland et al. [1986] made in situ balloon measurements from 20 to $31 \mathrm{~km}$ in Texas on November 4, 1981, and July 8, 1982. A comparison of their profiles shows a factor of 2 decrease in $\mathrm{NO}$ and $\mathrm{NO}_{2}$ below $25 \mathrm{~km}$, while near $30 \mathrm{~km}$ there is little difference. Also, Mankin and Coffey [1986] obtained a 50\% decrease in the total $\mathrm{NO}+\mathrm{NO}_{2}$ column abundance above $12 \mathrm{~km}$ but saw no change in $\mathrm{HNO}_{3}$. The model results show that the radiation and temperature changes produce only a few percent $\mathrm{NO}_{2}$ decrease, a slight $\mathrm{NO}$ increase, and little $\mathrm{HNO}_{3}$ change (see Table 1).

McFarland et al. [1986] found that their

$$
\frac{\left(\left[\mathrm{NO}_{2}\right] /[\mathrm{NO}]\right)_{\text {calculated }}}{\left(\left[\mathrm{NO}_{2}\right] /[\mathrm{NO}]\right)_{\text {measured }}}
$$

ratio varied from 0.7 to 1.3 from 20 to $30 \mathrm{~km}$. They obtained a ratio of 1.0 at $28 \mathrm{~km}$. Our diurnal results produce the same trend at noon in the partitioning of $\mathrm{NO}_{x}$ between $\mathrm{NO}$ and $\mathrm{NO}_{2}$ : a ratio of 1.0 at $28 \mathrm{~km}$ ( 0.9 below and 1.05 above $28 \mathrm{~km}$ ), when we take our no aerosol case to be their "calculated" case. (Their calculated ratio ignores the aerosol effect in the determination of $J_{9}$.) The "observed" case therefore corresponds to our aerosol containing case, where all the perturbations to the atmosphere are taken into account. The significance of this comparison depends on the definition of the McFarland et al. [1986] calculated case. Even in a nonvolcanically perturbed atmosphere (November 4,1981 ) they do not obtain a ratio of 1 from 20 to $31 \mathrm{~km}$ because of the uncertainty in determining $J_{9}$. Since the July 8,1982 , data show more deviation from unity, it suggests that their calculated $J_{9}$ value is affected by the volcanic aerosols, in a manner consistent with our calculations. We cannot com- pare our values directly with their $\left[\mathrm{NO}_{2}\right] /[\mathrm{NO}]_{\text {measured }}$ ratio, since McFarland et al. [1986] do not plot this separately.

The processes we have included in our model permit us to obtain the correct trend in the partitioning between NO and $\mathrm{NO}_{2}$ but do not lead to the observed $\mathrm{NO}_{x}$ decrease. Therefore, as in the case of $\mathrm{HCl}$ (see discussion following), other mechanisms must be considered.

$\mathrm{ClO}_{y}$. The total $\mathrm{ClO}_{y}\left(\left[\mathrm{ClNO}_{3}\right]+[\mathrm{HOCl}]+[\mathrm{HCl}]+[\mathrm{Cl}]\right.$ $+[\mathrm{ClO}])$ remains constant because the $\mathrm{Cl}$ source, the photodissociation of halocarbons, has not changed; therefore the changes in the concentrations of $\mathrm{Cl}$ species are due strictly to a "reshufling" of the chlorine between its reservoirs and between the reservoirs and reactive radicals. Elemental chlorine partitions itself between the major reservoir species $\mathrm{ClNO}_{3}, \mathrm{HOCl}$, and $\mathrm{HCl}$. The first has a weak $\mathrm{Cl}-\mathrm{ONO}_{2}$ bond $(20 \mathrm{kcal} / \mathrm{mol})$ and dissociates easily at long wavelengths (up to $4500 \AA$ ). $\mathrm{HOCl}$ is also weakly bound and dissociates shortward of $4200 \AA$. The aerosols have the effect of increasing the total radiation by about $8 \%$ at these wavelengths, leading to increased photodissociation rate constants for $\mathrm{ClNO}_{3}$ and $\mathrm{HOCl}$ of $8 \%$ and $7 \%$, respectively, at $26 \mathrm{~km}$ (Figure 4c). As a consequence, the abundances of $\mathrm{CINO}_{3}$ and $\mathrm{HOCl}$ drop by $8 \%$ and $7 \%$, respectively, at $26 \mathrm{~km}$, and in this reduced $\mathrm{NO}_{2}$ environment, the $\mathrm{Cl}$ liberated reacts with methane to form $\mathrm{HCl}$, which increases by $6 \%$ at $26 \mathrm{~km}$. The chemical stability of $\mathrm{HCl}$ is enhanced by the $10 \%$ decrease on its photodissociation rate constant.

$\mathrm{HCl}$ dissociates at wavelengths shorter than $2300 \AA$, in which spectral range there is a decrease in the radiation from 16 to $30 \mathrm{~km}$. The temperature perturbation enhances the $\mathrm{HCl}$ increase because of the positive temperature dependence of the reaction between $\mathrm{Cl}$ and $\mathrm{CH}_{4}$ (R61), increasing the production of $\mathrm{HCl}$ in the cloud, where the temperature increases. The methane does not show any change because its concentration is much larger than that of HCl. The destruction of $\mathrm{HCl}$ occurs by reaction with $\mathrm{OH}$ (R60) which only increases by $3-5 \%$, so its effect is minimal, and we obtain an $\mathrm{HCl}$ increase.

The total $\mathrm{ClO}_{x}([\mathrm{Cl}]+[\mathrm{ClO}])$ increase of $3.5 \%$ is simply because of the transfer of $\mathrm{Cl}$ from the reservoir to the active forms resulting from increased photodissociation of the reservoir species. This effect is offset by the increase in the rate of (R61) when the temperature effect is included. Both $\mathrm{Cl}$ and $\mathrm{ClO}$ increase as a consequence of the increase in $\mathrm{ClO}_{x}$. Figures 9 and 10 show the changes in all the $\mathrm{ClO}_{x}$ and $\mathrm{ClO}_{y}$ species.

The change in partitioning between $\mathrm{Cl}$ and $\mathrm{ClO}$, as expressed by the ratio

$$
\frac{[\mathrm{ClO}]}{[\mathrm{Cl}]}=\frac{k_{54}\left[\mathrm{O}_{3}\right]}{k_{55}[\mathrm{O}]+k_{56}[\mathrm{NO}]}
$$

decreases by $6 \%$ at $26 \mathrm{~km}$ because of the $2.6 \%$ ozone decrease and $4.0 \%$ NO and $3 \% \mathrm{O}$ increases. With the temperature change, the increase in $\mathrm{NO}$ is reduced at $26 \mathrm{~km}$, leading to a smaller $[\mathrm{ClO}] /[\mathrm{Cl}]$ decrease $(4.75 \%)$. The large $\mathrm{ClO}$ and $\mathrm{HO}_{2}$ increase with temperature below $22 \mathrm{~km}$ leads to a large $\mathrm{HOCl}$ increase (Figure 10) via (R68):

$$
\mathrm{HO}_{2}+\mathrm{ClO} \rightarrow \mathrm{HOCl}+\mathrm{O}_{2}
$$


Mankin and Coffey [1984] reported a hydrogen chloride column increase above $12 \mathrm{~km}$, from $20^{\circ}$ to $40^{\circ} \mathrm{N}$ latitude in September 1982, which they attributed to direct injection of chlorine directly from the volcano. Also, B. W. Gandrud and A. L. Lazrus (private communication, 1983) reported from in situ measurements an $\mathrm{HCl}$ increase from 21.6 to $27.4 \mathrm{~km}\left(32^{\circ} 52^{\prime} \mathrm{N}\right)$ in August 1982 (see Table 2).

We obtain a $10 \% \mathrm{HCl}$ increase at $24 \mathrm{~km}$ when the temperature perturbation is included, which is low compared with the observations of B. W. Gandrud and A. L. Lazrus (private communication, 1983). To compare our results with those of Mankin and Coffey [1984], we evaluated our $\mathrm{HCl}$ column abundance above $12 \mathrm{~km}$ and found a $1.7 \%$ increase, with the temperature effect. This is not enough to match the observations. Thus the simple changes in radiation field and temperature are not enough to explain the $\mathrm{HCl}$ observations. In a later section we will consider other possible explanations for the observed $\mathrm{HCl}$ increase.

\section{Heterogeneous Reactions INVOLVING THE VOLCANIC AEROSOLS}

It is clear from the above discussion, and from Table 2, that discrepancies between the model and observations of $\mathrm{HCl}, \mathrm{OH}, \mathrm{NO}$, and $\mathrm{NO}_{2}$ remain. We now shall consider an explanation for these discrepancies involving heterogeneous reactions on, or in, the sulfuric acid aerosol particles. There is a great deal of interest in heterogeneous reactions because of their importance in the polar stratospheric clouds (PSCs) in the Antarctic spring destruction of ozone. To solve the "ozone hole" problem, experimental physical chemists have focussed their attention on heterogeneous reactions on water ice surfaces [Molina et al., 1987; Leu, 1988a, b; Tolbert et al., 1987, 1988a] and on $\mathrm{H}_{2} \mathrm{SO}_{4} / \mathrm{H}_{2} \mathrm{O}$ drops [Rossi et al., 1987; Tolbert et al., 1988b; Worsnop et al., 1988]. The recent results of Tolbert et al. [1988b] and Worsnop et al. [1988] are particularly relevant when dealing with volcanic aerosols.

We investigated the following heterogeneous reactions, many of which have been proposed to explain the Antarctic ozone hole problem (for example, see review by Solomon [1988]):

$$
\begin{aligned}
\mathrm{ClNO}_{3} & \rightarrow \mathrm{HCl} * \\
\mathrm{ClNO}_{3}+\mathrm{HCl} & \rightarrow \mathrm{Cl}_{2}+\left(\mathrm{HNO}_{3}\right) \\
\mathrm{ClNO}_{3}+\mathrm{H}_{2} \mathrm{O} & \rightarrow \mathrm{HOCl}+\left(\mathrm{HNO}_{3}\right) \\
\mathrm{N}_{2} \mathrm{O}_{5}+\mathrm{H}_{2} \mathrm{O} & \rightarrow\left(2 \mathrm{HNO}_{3}\right) \\
\mathrm{Cl} & \rightarrow \mathrm{HCl} *
\end{aligned}
$$

(where the asterisk denotes speculative reactions in order to increase $\mathrm{HCl}$ directly.) In these reactions the $\mathrm{H}_{2} \mathrm{O}$ and $\mathrm{HCl}$ are preabsorbed in the aerosols. All other molecules are in the gas phase. It is uncertain whether or not the product $\mathrm{HNO}_{3}$ would remain in the aerosol or escape into the gas phase (thus the parentheses around $\mathrm{HNO}_{3}$ in the above reaction list). Laboratory experiments seem to suggest that $\mathrm{HNO}_{3}$ remains in the condensed phase; both eventualities were examined in our model runs.

The loss rate of a species through collisions with aerosols is

$$
J^{\prime}=\frac{1}{4} \gamma v A N_{a}
$$

where $\gamma$ is the sticking coefficient (combining the "sticking" and reaction efficiency), $v$ the thermal velocity of the gas $\left(3 \times 10^{4} \mathrm{~cm} \mathrm{~s}^{-1}\right), A$ the mean surface area $\left(6.4 \times 10^{-8} \mathrm{~cm}^{2}\right.$, assuming that the geometrical and optical cross sections are the same), and $N_{a}$, the number density of aerosols (at the peak of the aerosol cloud at $26 \mathrm{~km}, A N_{a}=9.4 \times 10^{-7} \mathrm{~cm}^{-1}$ ). At each altitude, for various $\gamma$, the loss rates of each reaction are evaluated and treated as first-order rate constants. At the time we performed our calculations, the results of Tolbert et al. [1988b] and Worsnop et al. [1988] were not known. The only information we had came from the experiments on water ice which gave sticking coefficients near 0.02 . This was a typical value used, which yielded a first-order rate of $2.5 \times 10^{-4} \mathrm{~s}^{-1}$ at the altitude of maximum aerosol concentration. The new results of Tolbert et al. [1988b] yield sticking coefficients near $3 \times 10^{-3}$ for (H2) and (H3) on a $65 \% \mathrm{H}_{2} \mathrm{SO}_{4} / 35 \% \mathrm{H}_{2} \mathrm{O}$ surface. Worsnop et al. [1988] presented a value of $\gamma=0.06$ for $(\mathrm{H} 4)$ on a $75 \%$ liquid sulfuric acid surface.

Reactions (H1) and (H5) were investigated to establish whether or not we could enhance $\mathrm{HCl}$ by producing it directly by some unknown heterogeneous mechanism. There is some experimental evidence suggesting that $\mathrm{HCl}$ is produced in a heterogeneous process involving $\mathrm{Cl}$ or ClO. Martin et al. [1980] obtained a reactivity coefficient for $\mathrm{Cl}$ and $\mathrm{ClO}$, at $220 \mathrm{~K}$ on $75 \% \mathrm{H}_{2} \mathrm{SO}_{4} / 25 \% \mathrm{H}_{2} \mathrm{O}$ films, of $3 \times 10^{-4}$ to $1 \times 10^{-3}$ and $3 \times 10^{-4}$ to $2 \times 10^{-3}$, respectively. In their earlier work, Martin et al. [1979] found that the product of the wall reaction with $\mathrm{Cl}$ and $\mathrm{ClO}$ was $\mathrm{HCl}$. Also, Leu [1988b] has evidence that the reaction probability of $\mathrm{ClO}$ on ice is greater than 0.01 at $190 \mathrm{~K}$. Even though these experiments are not without uncertainties, they suggest that $\mathrm{Cl} / \mathrm{ClO}$ might produce $\mathrm{HCl}$ heterogeneously with a $\gamma$ in the range that we have found to affect the $\mathrm{HCl}$ abundance in a manner consistent with observations. It is clear that further experimental investigations on these reactions are needed.

The available measurements tightly constrain the nature of possible heterogeneous processes. In general, calculations in which product $\mathrm{NO}_{y}$ did not return to the gas phase most closely approximated the observations in Table 1. In particular, (H1) best reproduces the available observational data. The results of model calculations in which (H1) was included (and the assumption made that product $\mathrm{NO}_{y}$ remains in the aerosol) are summarized in Figure 11 and reported also in Table 1 for direct comparison with measurements. The calculations were carried out as described in an earlier section, except the run was terminated after an elapsed time of 3 months to simulate the delay between the volcanic eruption and time of observations and to avoid any significant problems with mass balance.

With the insight gained from previous sections, we can understand the calculated consequences of the inclusion of (H1) in our reaction list. The direct conversion of $\mathrm{ClNO}_{3}$ to $\mathrm{HCl}$ in ( $\mathrm{H1}$ ) leads to a significant increase in the calculated $\mathrm{HCl}$ abundances, more than doubling at altitudes where the $\mathrm{ClNO}_{3}$ density exceeds the $\mathrm{HCl}$ density in the "unperturbed" atmosphere (such is the situation in the lower stratosphere [cf. Raper et al., 1987]). The reduction in the gas phase $\mathrm{NO}_{x}$ abundances (denoxification) decreases the overall catalytic $\mathrm{NO}_{x}$ destruction of odd oxygen and increases (in a relative sense) the $\mathrm{O}_{3}$ concentration near $30 \mathrm{~km}$, because the primary chemical loss of odd oxygen in most of the 


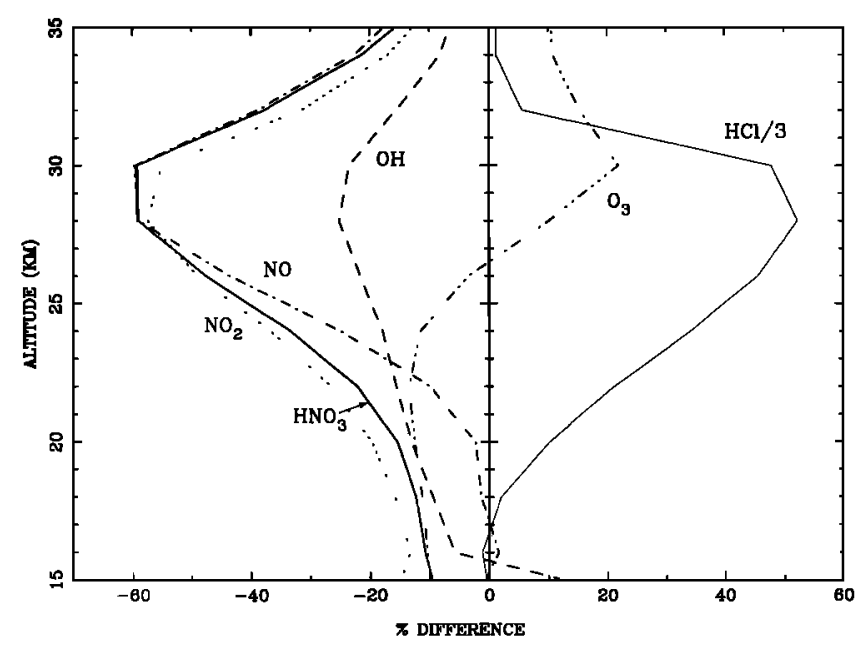

Fig. 11. The percent difference in the concentrations of $\mathrm{O}_{3}, \mathrm{OH}$, $\mathrm{NO}, \mathrm{NO}_{2}, \mathrm{HNO}_{3}$, and $\mathrm{HCl}$ at $20^{\circ} \mathrm{N}$ for a local time of 1400 (solar zenith angle of $45^{\circ}$ ). The model calculations include changes in the radiation field and temperature and incorporate the heterogeneous chemical reaction $\mathrm{ClNO}_{3} \rightarrow \mathrm{HCl}$ (H1).

stratosphere is due to the $\mathrm{NO}_{x}$ catalytic cycle. In the lower stratosphere the $\mathrm{O}_{2}$ photolysis producing odd oxygen occurs in the long wavelength tail of the Herzberg continuum, a spectral range in which $\mathrm{O}_{3}$ opacity affects the penetration of solar radiation. The $\mathrm{O}_{3}$ increase at $30 \mathrm{~km}$ results in reduced $\mathrm{O}_{2}$ photolysis at $24 \mathrm{~km}$ and, consequently, an additional decrease in $\mathrm{O}_{3}$ at $24 \mathrm{~km}$ (in a relative sense). The assumption of product nitrogen species sequestered in the aerosols, however, necessarily leads to a decrease in gaseous $\mathrm{HNO}_{3}$, which was not observed.

While our choice of $\gamma=0.02$ for (H2) is obviously an upper limit in light of recent laboratory results, cases calculated with $\gamma$ as low as $10^{-4}$ all show extremely rapid decreases in $\mathrm{HCl}$ within the aerosol cloud, with the chlorine being repartitioned into other species, in conflict with the observations of a large $\mathrm{HCl}$ increase after the volcanic eruption. We note a similar decrease in $\mathrm{HCl}$ in our model results when (H3) is included with $\gamma$ as low as $10^{-4}$, because $\mathrm{HOCl}$ is more photolytically stable than $\mathrm{ClNO}_{3}$. Therefore less $\mathrm{Cl}$ is released, when it is in the $\mathrm{HOCl}$ form, for possible reaction to form $\mathrm{HCl}$.

Reaction (H4) was suggested by Roscoe et al. [1986] as a possible mechanism for the observed $\mathrm{NO}_{x}$ depletion. In the calculations in which (H4) was included (and product $\mathrm{HNO}_{3}$ sequestered in the aerosols), $\mathrm{NO}_{x}$ decreased and $\mathrm{HCl}$ increased. Since $\mathrm{NO}_{2}$ is unavailable to form $\mathrm{ClNO}_{3}, \mathrm{Cl}$ is free to form $\mathrm{HCl}$. Reaction (H4) is a good candidate to explain part of the observations of concentration changes after the El Chichon eruption. However, (H1) produced a larger increase in $\mathrm{HCl}$ abundances and not as large a decrease in the $\mathrm{HNO}_{3}$ values. Moreover, a consequence of the larger overall denitrification as a result of (H4), there is a larger relative $\mathrm{O}_{3}$ increase with (H4) than with (H1), which does not agree with observations.

Reaction (H5) was investigated to establish whether or not we could enhance $\mathrm{HCl}$ by producing it directly by some unknown heterogeneous mechanism not involving nitrogencontaining components. While this is possible with $\gamma=0.01$ (or $J^{\prime}=1.2 \times 10^{-4} \mathrm{~s}^{-1}$ ), the inclusion of (H5) produces changes in $\mathrm{NO}$ and $\mathrm{NO}_{2}$ in the opposite sense of what the observations show. Increases in $\mathrm{NO}$ and $\mathrm{NO}_{2}$ result because the chlorine, that normally sequesters $\mathrm{NO}_{x}$ in the form of $\mathrm{ClNO}_{3}$, is now tied up in $\mathrm{HCl}$.

A final suggestion to denitrify the stratosphere, which is even more speculative than the previous explanations, is that $\mathrm{NO}$ and $\mathrm{NO}_{2}$ are adsorbed onto the aerosols. This is consistent with the observed large $\mathrm{NO}_{x}$ decrease. In this case, $\mathrm{Cl}$ from $\mathrm{ClNO}_{3}$ dissociation is free to react with the large $\mathrm{CH}_{4}$ reservoir to form the extra $\mathrm{HCl}$ that is observed. However, McKeen et al. [1984] calculated the loss rate of $\mathrm{NO}_{2}$ and $\mathrm{HNO}_{3}$ to a distribution of particles and found that $\mathrm{NO}_{x}$ would be completely depleted in a few days, which is not confirmed by observations.

Hofman and Solomon [1989] specifically studied the effect of heterogeneous reactions on the El Chichon volcanic aerosols using a two-dimensional model. Neglecting the radiation and temperature effects, they obtain results for $\mathrm{O}_{3}$, $\mathrm{NO}_{2}, \mathrm{OH}$, and $\mathrm{HNO}_{3}$ in qualitative agreement with ours when we include heterogeneous reactions. Since they focussed on chemistry previously proposed for the Antarctic hole scenario (such as (H2), (H3), and (H4)), the discussion above can explain their result of an $\mathrm{HCl}$ decrease, contrary to the observed increase.

The heterogeneous mechanisms we have considered directly affect the $\mathrm{NO}_{x}$ and $\mathrm{ClO}_{x}$ species. Each of the heterogeneous reactions has a different effect on the $\mathrm{O}_{3}$ profile. Reaction (H3) results in a significant decrease in the $\mathrm{O}_{3}$ profile because of a substantial increase in ClO. In the case of the other reactions, the perturbation on the $\mathrm{O}_{3}$ abundances due to the radiation and temperature effects discussed earlier in this paper is slightly increased or decreased depending on the magnitude of the $\mathrm{NO}_{x}$ depletion.

Our conclusion is that heterogeneous chemistry needs to be included in photochemical models to explain the changes observed after the El Chichon volcanic eruption. This parallels recent findings concerning the Antarctic ozone hole. Our analysis shows that the heterogeneous reaction between $\mathrm{ClNO}_{3}$ and sulfuric acid aerosols to form $\mathrm{HCl}(\mathrm{H} 1)$, yields results that agree reasonably well with the observations after the volcanic eruption. Considering the uncertainties in a one-dimensional simulation, and the lack of definitive laboratory results on heterogeneous processes, our agreement with observations is encouraging.

\section{DIRECT INJECTIONS OF VOLCANIC GASES INTO THE STRATOSPHERE}

Due to the obviously speculative nature of (H1), we cannot claim that it is the only reaction that can account for the observations. We therefore must investigate an equally speculative scenario involving injection of gases directly into the stratosphere from the eruption of the volcano. This possibility is substantiated by the fact that many volcanos are known to eject gases other than $\mathrm{SO}_{2}$, such as $\mathrm{Cl}_{2}, \mathrm{HCl}$, or $\mathrm{H}_{2} \mathrm{O}$ [Cadle, 1975, 1980].

Woods et al. [1985] discussed the implications of the decrease in $\mathrm{NaCl}$ concentrations they observed in the volcanic plume from May to July 1982. They state that the $\mathrm{NaCl}$ lost in the plume reacted with $\mathrm{H}_{2} \mathrm{SO}_{4}$ to form the $\mathrm{HCl}$ observed by Mankin and Coffey [1984] and B. W. Gandrud and A. L. Lazrus (private communication, 1983). We estimate the amount of $\mathrm{Cl}$ injected using the difference in halite concentrations in the volcanic plume measured by Woods et al. 


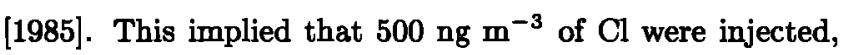
resulting in a $0.2 \mathrm{ppb}$ extra chlorine loading between 18 and $21 \mathrm{~km}$. The extra $\mathrm{Cl}$ for other altitudes was estimated relative to the amount of aerosol at that level. The chlorine was first added to our model in the form of $\mathrm{Cl}$ atoms and corresponded to a maximum possible $\mathrm{HCl}$ increase of $\mathbf{4 0 \%}$ at $28 \mathrm{~km}$. The calculations performed included the radiation field and temperature perturbations and resulted in very little change in the final $\mathrm{HCl}$ concentration.

We also considered the case in which the volcano injected $\mathrm{HCl}$ itself into the stratosphere. The recent paper by Symonds et al. [1988] states that $\mathrm{HCl}$ is the dominant chlorine-containing compound in volcanic gases. However, our calculations show that very little of the $\mathrm{HCl}$ initially injected, estimated from the Woods et al. [1985] data, remained in the stratosphere 3 months later. Given these results, to obtain a $40 \%$ increase in $\mathrm{HCl}$ at $28 \mathrm{~km} 3$ months after the eruption, an $\mathrm{HCl}$ column increase of $60 \%$ above $12 \mathrm{~km}$ (or a $820 \% \mathrm{HCl}$ increase at $28 \mathrm{~km}$ ) is necessary. The $\mathrm{HCl}$ injected reacts with $\mathrm{OH}$ to form $\mathrm{Cl}(\mathrm{R} 60)$, which rapidly equilibrates with $\mathrm{ClO}((\mathrm{R} 54)$ and (R55)). With normal atmospheric $\mathrm{NO}_{2}$ concentrations, the formation of $\mathrm{ClNO}_{3}$ is preferred over that of $\mathrm{HCl}$, while its destruction is more rapid. The extra $\mathrm{Cl}$ will partition itself among the other chlorine species in order to return the $[\mathrm{Cl}] /[\mathrm{HCl}]$ ratio to the preinjection steady state value.

Besides this "chemical" loss of $\mathrm{HCl}$, there is also a loss because of transport to the troposphere, and rainout below $16 \mathrm{~km}$. The large gradient in $\mathrm{ClO}_{y}$ concentration after the injection of $\mathrm{HCl}$ increases the downward flux of species. The rainout represents $70 \%$ of the loss of injected $\mathrm{HCl}$ when we consider a $60 \%$ column increase. There are no observations of such a large direct injection of $\mathrm{HCl}$ after El Chichon. There is evidence presented by Symonds et al. [1988] that the large explosive eruption of Toba $(75,000$ years B.P.), Tambora (1815) and Krakatau (1883) could have contributed enough $\mathrm{HCl}$ to the atmosphere. Based on our work, if a substantial fraction of the $\mathrm{HCl}$ were directly injected into the stratosphere, the chemical perturbations could have been severe. It is difficult to quantify the exact effect of these eruptions on ozone, but it is clear that any recorded smaller eruption could not have affected ozone by an $\mathrm{HCl}$ injection, since the $\mathrm{HCl}$ would quickly return to its steady state value.

It might also be possible to decrease the $\mathrm{NO}$ and $\mathrm{NO}_{2}$ content of the atmosphere by a direct injection of $\mathrm{H}_{2} \mathrm{O}$ from the volcano. However, Thomas et al. [1983] suggested that there was less than a $20 \%$ increase in water, while Roscoe et al. [1986] estimated that $20 \mathrm{ppmv}$ of $\mathrm{H}_{2} \mathrm{O}$ would have to be injected to produce the observed $\mathrm{NO}_{x}$ decrease. If 20 ppmv of $\mathrm{H}_{2} \mathrm{O}$ are added to our model, the $\mathrm{NO}$ and $\mathrm{NO}_{2}$ concentrations are reduced by about $20 \%$ (after 3 months), which is still not sufficient to explain the observations.

Including 20 ppmv of water in our model also produces a $20 \%$ OH increase at $24 \mathrm{~km}$, but again the column changes by only a few percent. In order to obtain a $30 \%$ column increase in $\mathrm{OH}$ [Burnett and Burnett, 1984], a substantial amount of water has to be injected around $40 \mathrm{~km}$ (which is unobserved). Any large $\mathrm{H}_{2} \mathrm{O}$ increase has a direct impact on the $\mathrm{HCl}$ loss rate. The inclusion of $20 \mathrm{ppmv}$ of $\mathrm{H}_{2} \mathrm{O}$ leads to a $15 \% \mathrm{HCl}$ loss, in contradiction with the observations.

Unfortunately, the injection of a single species does not explain all the data. It is also unlikely that the large amounts required to produce the observed stratospheric changes were actually injected into the stratosphere. For this reason, we consider the explanation based on (H1) discussed in the previous section to be more plausible than direct injection.

\section{CONCluSiON}

Our radiative transfer calculations predict that the sudden increase in stratospheric aerosols due to the El Chichon eruption caused a $10 \%$ increase in the actinic flux longward of $3500 \AA$ between 16 and $30 \mathrm{~km}$. In regions of large gaseous optical depth, the total radiation decreased by $15 \%$ within the volcanic aerosol layer. These changes in the actinic flux have a direct impact on stratospheric photodissociation rate constants. $\mathrm{O}_{3}, \mathrm{NO}_{2}, \mathrm{NO}_{3}, \mathrm{ClNO}_{3}$, and $\mathrm{HOCl}$ have absorption cross sections between 3000 and $8000 \AA$ and are among the species whose photodissociation rate constants increase by $10 \%$, while those of $\mathrm{O}_{2}, \mathrm{H}_{2} \mathrm{O}, \mathrm{NO}$, and $\mathrm{HCl}$, absorbing below $3000 \AA$, decrease by $15 \%$ at altitudes within the aerosol cloud.

The radiation and temperature changes are observed atmospheric perturbations that affect the concentrations of species in various ways. For example, the model predicted a $7 \% \mathrm{O}_{3}$ decrease at $24 \mathrm{~km}$, in agreement with observations. This is due to both a $6 \%$ decrease in the photodissociation rate constant of $\mathrm{O}_{2}$ and a $7 \%$ increase in the $[\mathrm{O}] /\left[\mathrm{O}_{3}\right]$ ratio. The latter results from a change in the partitioning between $\mathrm{O}$ and $\mathrm{O}_{3}$ because of increased ozone photodissociation and the decreased rate of the ozone formation reaction (from $\left.\mathrm{O}+\mathrm{O}_{2}+M\right)$.

The changes in $\mathrm{HO}_{x}$ follow the changes in $\mathrm{O}\left({ }^{1} D\right)$ concentrations. The explanation of the details in the partitioning between $\mathrm{OH}$ and $\mathrm{HO}_{2}$ depends on $\mathrm{NO}_{x}$ chemistry. Our model predicts little $\mathrm{NO}_{x}$ change, but an $\left[\mathrm{NO}_{2}\right] /[\mathrm{NO}]$ ratio decrease of $6 \%$ because of increased photodissociation of $\mathrm{NO}_{2}$.

The calculated $10 \%$ increase in $\mathrm{HCl}$ is explained by an enhanced release of $\mathrm{Cl}$ from $\mathrm{ClNO}_{3}$ and $\mathrm{HOCl}$ reservoirs. While $\mathrm{ClO}_{y}$ remains constant, because there is no change in halocarbon photodissociation, the $\mathrm{ClO}_{x} / \mathrm{ClO}_{y}$ ratio increases because of the enhanced photodissociation of chlorine reservoir species.

Heterogeneous reactions such as those invoked to denitrify the polar stratosphere and precondition the early spring chemistry probably occurred on the volcanic aerosols. Of all heterogeneous reactions explored in the model, we favor the reaction $\mathrm{ClNO}_{3} \rightarrow \mathrm{HCl}$. This reaction results in a decrease of $\mathrm{NO}$ and $\mathrm{NO}_{2}$ and an increase in $\mathrm{HCl}$ concentrations, consistent with observations.

If the observation of a $40 \% \mathrm{HCl}$ increase is caused by a direct injection of gas into the stratosphere, we conclude that an initial $\mathrm{HCl}$ column increase above $12 \mathrm{~km}$ of $60 \%$ is required. This large injection has not been confirmed by observation. Any $\mathrm{HCl}$ added to the stratosphere is quickly removed by transport to the troposphere and redistribution of $\mathrm{Cl}$ among the other species. A large direct injection of water decreases $\mathrm{NO}_{x}$ and $\mathrm{HCl}$ and increases $\mathrm{OH}$. Unfortunately, the change is not sufficient to explain the $\mathrm{NO}_{x}$ and $\mathrm{OH}$ observations and contradicts the increase in $\mathrm{HCl}$ measured.

These investigations are a challenge to our model. The agreement between the model predictions, based on observed atmospheric perturbations, and the measured atmo- 
spheric consequences of these perturbations (see Table 1 ) is very good. Therefore the processes described in the model seem to be an almost complete description of the Earth's stratosphere. We can extend this work to a case of an early Earth, with many active volcanos erupting every year. The consequences on the chemistry and radiation of the atmosphere might be significant in modeling the subsequent evolution to present-day conditions.

One of the least understood aspects of the chemistry of the Earth's stratosphere is that of the effect of aerosols. The optical and chemical properties of these particles are not yet fully understood. Therefore their effect on other atmospheric species and on the radiation field is not clearly known. We therefore need more laboratory studies of aerosols which should include the critical information on heterogeneous, aqueous-phase reaction rates. It would then be less difficult to include them in realistic theoretical models of the atmosphere.

Acknowledgments. The authors wish to thank T. P. Ackerman and J. B. Pollack for providing the results of their optical calculations. Communications, prior to publication, from W. G. Mankin, B. A. Ridley, M. McFarland, S. Chandra, and T. Clancy are greatly appreciated. This work has also benefited from numerous discussions with M. J. Molina, M. T. Leu, R. R. Friedl, S. P. Sander, and W. B. DeMore. The comments of S. Solomon and anonymous reviewers have helped us improve the manuscript. This research was supported by NASA grant NAGW-413. Division of Geological and Planetary Sciences, California Institute of Technology, contribution 4197.

\section{REFERENCES}

Adriani, A., F. Congeduti, G. Fiocco, and G. P. Gobbi, One-year observations of the stratospheric aerosol at Frascati, March 1982-March 1983, Geophys. Res. Lett., 10, 1005-1008, 1983.

Adriani, A., G. Fiocco, G. P. Gobbi, and F. Congeduti, Correlated behavior of the aerosol and ozone contents of the stratosphere after the El Chichon eruption, J. Geophys. Res., 92, 83658372, 1987.

Angell, J. K., An update through 1985 of the variations in global total ozone and north temperate layer-mean ozone, J. Appl. Meteorol, 27, 91-97, 1988.

Angell, J. K., J. Korshover, and W. G. Planet, Ground-based and satellite evidence for a pronounced total-ozone minimum in early 1983 and responsible atmospheric layers, Mon. Weather Rev., 119, 641-646, 1985.

Bais, A. F., C. S. Zerefos, T. C. Ziomas, N. Zoumakis, H. T. Mantis, D. J. Hofmann, and G. Fiocco, Decrease in the ozone and the $\mathrm{SO}_{2}$ columns following the appearance of the El Chichon aerosol cloud at midlatitude, in Atmospheric Ozone, edited by C. S. Zerefos and A. Ghazi, pp. 353-356, D. Reidel, Hingham, Mass., 1985.

Barth, C. A., R. W. Sanders, R. J. Thomas, G. E. Thomas, B. M. Jakosky, and R. A. West, Formation of the El Chichon aerosol cloud, Geophys. Res. Lett., 10, 993-996, 1983.

Burnett, C. R., and E. B. Burnett, Observational results on the vertical column abundance of atmospheric hydroxyl: Description of its seasonal behavior 1977-1982 and of the $1982 \mathrm{El} \mathrm{Chi-}$ chon perturbation, J. Geophys. Res., 89, 9603-9611, 1984.

Cadle, R. D., Volcanic emissions of halides and sulfur compounds to the troposphere and stratosphere, J. Geophys. Res., 80, 16501652,1975 .

Cadle, R. D., Some effects of the emissions of explosive volcanos on the stratosphere, J. Geophys. Res., 85, 4495-4498, 1980.

Chandra, S., The aerosol effects on ozone measurements following the eruption of El Chichon, Eos Trans. AGU, 68, 370, 1987.

Cicerone, R. J., S. Walters, and S. C. Liu, Nonlinear response of stratospheric ozone column to chlorine injections, J. Geophys. Res., 88, 3647-3661, 1983.

Clarke, A. D., R. J. Charlson, and J. A. Ogren, Stratospheric aerosol light absorption before and after El Chichon, Geophys. Res. Lett., 10, 1017-1020, 1983.

DeLuisi, J. J., E. G. Dutton, K. L. Coulson, T. E. DeFoor, and B. G. Mendonca, On some radiative features of the El Chichon volcanic stratospheric dust cloud and a cloud of unknown origin observed at Mauna Loa, J. Geophys. Res., 88, 6769-6772, 1983.

DeLuisi, J. J., C. L. Mateer, and W. D. Komhyr, Effects of the El Chichon aerosol cloud on Umkher measurements at Mauna Loa, Hawaii, in Atmospheric Ozone, edited by C. S. Zerefos and A. Ghazi, pp. 316-320, D. Reidel, Hingham, Mass., 1985.

DeMore, W. B., J. J. Margitan, M. J. Molina, R. T. Watson, D. M. Golden, R. F. Hampson, M. J. Kurylo, C. J. Howard, and A. R. Ravishankara, Chemical kinetics and photochemical data for use in stratospheric modeling, JPL Publ, 85-37, 1985.

Farman, J. C., B. G. Gardiner, and J. D. Shanklin, Large losses of total ozone in Antarctica reveal seasonal $\mathrm{ClO}_{x} / \mathrm{NO}_{x}$ interaction, Nature, $315,207-210,1985$.

Froidevaux, L., M. Allen, and Y. L. Yung, A critical analysis of $\mathrm{ClO}$ and $\mathrm{O}_{3}$ in the mid-latitude stratosphere, J. Geophys. Res., $90,12,999-13,029,1985$.

Gladstone, G. R., Radiative transfer with partial frequency redistribution in inhomogeneous atmosphere: Application to the Jovian aurora, J. Quant. Spectrosc. Radiat. Transfer, 27, 545-556, 1982.

Hansen, J. E., and L. D. Travis, Light scattering in planetary atmospheres, Space Sci. Rev., 16, 527-610, 1974.

Heath, D. F., and B. H. Schlesinger, Global response of stratospheric ozone to natural perturbations on climatological time scales by variations of UV solar flux and the eruption of El Chichon, Eos Trans. AGU, 65, 836-837, 1984.

Hofmann, D. J., and J. M. Rosen, Stratospheric sulfuric acid fraction and mass estimate for the 1982 volcanic eruption of El Chichon, Geophys. Res. Lett., 10, 313-316, 1983.

Hofmann, D. J., and R. M. Rosen, On the temporal variation of stratospheric aerosol size and mass during the first 18 months following the 1982 eruptions of El Chichon, J. Geophys. Res., 89, 4883-4890, 1984.

Hofmann, D. J., and S. Solomon, Ozone destruction through heterogeneous chemistry following the eruption of El Chichon, $J$. Geophys. Res., 94, 5029-5041, 1989.

Jäger, $H$., and W. Carnuth, The decay of the El Chichon stratospheric perturbation, observed by lidar at northern midlatitudes, Geophys. Res. Lett., 14, 696-699, 1987.

Knollenberg, R. G., and D. Huffman, Measurements of the aerosol size distributions in the El Chichon cloud, Geophys. Res. Lett., 10, 1025-1028, 1983.

Komhyr, W. D., S. J. Oltmans, A. N. Chopra, R. K. Leonard, T. E. Garcia, and C. McFee, Results of Umkher, ozonesonde, total ozone, and sulfur dioxide observations in Hawaii following the eruption of El Chichon volcano in 1982, in Atmospheric Ozone, edited by C. S. Zerefos and A. Ghazi, pp. 305-310, D. Reidel, Hingham, Mass., 1985.

Krueger, A. J., Sighting of El Chichon sulfur dioxide clouds with Nimbus 7 total ozone mapping spectrometer, Science, 220, 1377, 1983.

Labitzke, K., B. Naujokat, and M. P. McCormick, Temperature effects on the stratosphere of the April 4, 1982 eruption of E1 Chichon, Mexico, Geophys. Res. Lett., 10, 24-26, 1983.

Leu, M.-T., Laboratory studies of sticking coefficients and heterogeneous reactions important in the antarctic stratosphere, Geophys. Res. Lett., 15, 17-20, 1988a.

Leu, M.-T., Heterogeneous reactions of $\mathrm{N}_{2} \mathrm{O}_{5}$ with $\mathrm{H}_{2} \mathrm{O}$ and $\mathrm{HCl}$ on ice surfaces: Implications for Antarctic ozone depletion, Geophys. Res. Lett., 15, 851-854, 1988 b.

Liou, K.-N., An Introduction to Atmospheric Radiation, vol. 26, pp. 55, Academic, San Diego, Calif., 1980.

Luther, F. M., and R. J. Gelinas, Effect of molecular multiple scattering and surface albedo on atmospheric photodissociation rates, J. Geophys. Res., 81, 1125-1132, 1976.

Mankin, W. G., and M. T. Coffey, Increased stratospheric hydrogen chloride in the El Chichon cloud, Science, 226, 170-172, 1984.

Mankin, W. G., and M. T. Coffey, The impact of El Chichon on the chemistry of the stratosphere, paper presented at the Norman D. Watkins Symposium on the Environmental Impact of Volcanism, Graduate School of Oceanography, Narragansett, R.I., March 1986. 
Mantis, H. T., C. S. Zerefos, A. Bais, I. Ziomas, and A. Kelessis, The northern hemisphere ozone minimum in 1982-1983, Arch. Meteorol. Geophys. Bioclimatol., Ser. B, S6, 135-145, 1986.

Martin, L. R., A. G. Wren, and M. Wun, Chlorine atom and $\mathrm{ClO}$ wall reaction products, Int. J. Chem. Kinet., 11, 543-547, 1979.

Martin, L. R., H. S. Judeikis, and M. Wun, Heterogeneous reactions of $\mathrm{Cl}$ and $\mathrm{ClO}$ in the stratosphere, J. Geophys. Res., 85, 5511-5518, 1980.

McElroy, M. B., and R. J. Salawitch, Changing composition of the global stratosphere, Science, 248, 763-770, 1989.

McElroy, M. B., R. J. Salawitch, and S. C. Wofsy, Antarctic ozone: Reduction due to synergistic interactions of chlorine and bromine, Nature, $\$ 21,759-762,1986$.

McFarland, M., B. A. Ridley, M. H. Proffitt, D. L. Albritton, T. L. Thompson, W. J. Harrop, R. H. Winkler, and A. L Schmeltekopf, Simultaneous in situ measurements of $\mathrm{NO}_{2}, \mathrm{NO}$ and $\mathrm{O}_{3}$ between 20 and $31 \mathrm{~km}$., J. Geophys. Res., 91, 5421-5437, 1986.

McKeen, S. A., S. C. Liu, and C. S. Kiang, On the chemistry of stratospheric $\mathrm{SO}_{2}$ from volcanic eruptions, J. Geophys. Res., 89, 4873-4881, 1984.

Molina, M. J., and F. S. Rowland, Stratospheric sink for chlorofluoromethanes: Chlorine atom catalyzed destruction of ozone, Nature, 249, 810-812, 1974.

Molina, M. J., T. L. Tso, L. T. Molina, and F. C. Y. Wang, Antarctic stratospheric chemistry of chlorine nitrate, hydrogen chloride and ice: Release of active chlorine, Science, 2\$8, 1253$1257,1987$.

Pollack, J. B., O. B. Toon, E. F. Danielson, D. J. Hofmann, and J. M. Rosen, The El Chichon volcanic cloud: An introduction, Geophys. Res. Lett., 10, 989-992, 1983.

Pollack, J. B., and T. P. Ackerman, Possible effects of the E1 Chichon volcanic cloud on the radiation budget of the northern tropics, Geophys. Res. Lett., 10, 1057-1060, 1983.

Prather, M. J., M. B. McElroy, and S. C. Wofsy, Reductions in ozone at high concentrations of stratospheric halogens, Nature, 312, 227-231, 1984.

Quiroz, R. S., The isolation of stratospheric temperature change due to the El Chichon volcanic eruption from nonvolcanic signals, J. Geophys. Res., 88, 6773-6780, 1983.

Raper, O. F., C. B. Farmer, R. Zander, and J. H. Park, Infrared spectroscopic measurements of halogenated sink and reservoir gases in the stratosphere with the ATMOS instrument, J. Geophys. Res., 92, 9851-9858, 1987.

Roscoe, H. K., B. J. Kerridge, L. J. Gray, R. J. Wells, and J. A. Pyle, Simultaneous measurements of stratospheric NO and $\mathrm{NO}_{2}$, and their comparison with model predictions, $J$. Geophys. Res., 91, 5405-5419, 1986.

Rosenfield, J. E., M. R. Schoeberl, and M. A. Geller, A computation of the diabatic circulation using an accurate radiative transfer model, J. Atmos. Sci., 44, 859-876, 1987.

Rossi, M. J., R. Malhotra, and D. M. Golden, Heterogeneous chemical reaction of chlorine nitrate and water on sulfuric-acid surfaces at room temperature, Geophys. Res. Lett., 14, 127-130, 1987.

Rowland, F. S., and M. J. Molina, Chlorofluoromethanes in the environment, Rev. Geophys., 13, 1-35, 1975.
Shibata, T., M. Fujiwara, and M. Hirono, The El Chichon volcanic cloud in the stratosphere: Lidar observation at Fukuoka and numerical simulation, J. Atmos. Terr. Phys., 46, 1121-1146, 1984

Solomon, S., The mystery of the Antarctic ozone "hole," Rev. Geophys., 26, 131-148, 1988.

Solomon, S., R. R. Garcia, F. S. Rowland, and D. J. Wuebbles, On the depletion of Antarctic ozone, Nature, 321, 755-758, 1986.

Spinhirne, J. D., and M. D. King, Latitude variation of spectral thickness and columnar size distribution of the El Chichon stratospheric aerosol layer, J. Geophys. Res., 90, 10,607-10,619, 1985.

Symonds, R. B., W. I. Rose, and M. H. Reed, Contribution of Cland F-bearing gases to the atmosphere by volcanos, Nature, 994, 415-418, 1988.

Thomas, G. E., B. M. Jakosky, R. A. West, and R. W. Sanders, Satellite limb-scanning thermal infrared observations of the El Chichon stratospheric aerosol: First results, Geophys. Res. Lett., 10, 997-1000, 1983.

Tolbert, M. A., M. J. Rossi, R. Malhotra, and D. M. Golden, Reaction of chlorine nitrate with hydrogen chloride and water at Antarctic stratospheric temperatures, Science, 238, 1258-1260, 1987.

Tolbert, M. A., M. J. Rossi, and D. M. Golden, Antarctic ozone depletion chemistry: Reactions of $\mathrm{N}_{2} \mathrm{O}_{5}$ with $\mathrm{H}_{2} \mathrm{O}$ and $\mathrm{HCl}$ on ice surfaces, Science, 240, 1018-1021, 1988a.

Tolbert, M. A., M. J. Rossi, and D. M. Golden, Heterogeneous interactions of chlorine nitrate, hydrogen chloride, and nitric acid with sulfuric acid surfaces at stratospheric temperatures, Geophys. Res. Lett., 15, 847-850, 1988 .

Van de Hulst, H. C., Multiple Light Scattering: Tables, Formulas, and Applications, vol. 2, pp. 303-317, Academic, San Diego, Calif., 1980 .

Wang, P. W., and M. P. McCormick, Variations in stratospheric aerosol optical depth during northern warmings, J. Geophys. Res., 90, 10,597-10,606, 1985.

Watson, R. T. (Ed.-in-Chief), et al., Atmosphere ozone 1985: Assessment of our understanding of the processes controlling its present distribution and change, Rep. 16, Global Ozone Research and Monitoring Project, World Meteorol. Organ., Geneva, 1985.

Woods, D. C., R. L. Chuan, and W. I. Rose, Halite particles injected into the stratosphere by the 1982 El Chichon eruption, Science, 230, 170-172, 1985.

Worsnop, D., M. Zahniser, C. Kolb, L. Watson, J. Van Doren, J. Jayne, and P. Davidovits, Mass accommodation coefficient measurements for $\mathrm{HNO}_{3}, \mathrm{HCl}$, and $\mathrm{N}_{2} \mathrm{O}_{5}$ on water, ice and aqueous sulfuric acid droplet surfaces, paper presented at the Polar Ozone Workshop, Snowmass, Colo., May 9-13, 1988.

M. Allen, D. V. Michelangeli, and Y. L. Yung, Division of Geological and Planetary Sciences, California Institute of Technology, Pasadena, CA 91125.

(Received September 30, 1988; revised May 30, 1989; accepted May 30, 1989.) 